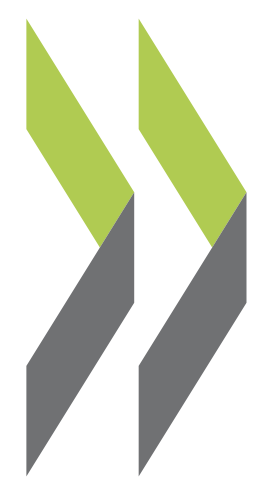

OECD Working Papers on International Investment 2014/03

\title{
Investment Treaties \\ and Shareholder Claims: Analysis of Treaty Practice
}

David Gaukrodger 


\section{OECD WORKING PAPERS ON INTERNATIONAL INVESTMENT}

The international investment working paper series - including policies and trends and the broader implications of multinational enterprise - is designed to make available to a wide readership selected studies by the OECD Investment Committee, OECD Investment Division staff, or outside consultants working on OECD Investment Committee projects.

The papers are generally available only in their original language (English or French) with a summary in the other if available. Comments on Working Papers are welcome, and may be sent to investment@oecd.org or the Investment Division, OECD, 2 rue André Pascal, 75775 Paris Cedex 16, France.

OECD WORKING PAPERS ON INTERNATIONAL INVESTMENT

are published on www.oecd.org/daf/inv/investment-policy/working-papers.htm.

OECD Working Papers should not be reported as representing the official views of the OECD or of its member countries. The opinions expressed and arguments employed are those of the authors.

Working Papers describe preliminary results or research in progress by the author(s) and are published to stimulate discussion on a broad range of issues on which the OECD works. Comments on Working Papers are welcome, and may be sent to investment@oecd.org or the Investment Division, OECD, 2 rue André Pascal, 75775 Paris Cedex 16, France.

This document and any map included herein are without prejudice to the status of or sovereignty over any territory, to the delimitation of international frontiers and boundaries and to the name of any territory, city or area.

Applications for permission to reproduce or translate all or part of this material should be made to: OECD Publishing, rights@oecd.org or by fax 33145249930 . 


\title{
Investment Treaties and Shareholder Claims: Analysis of Treaty Practice
}

\author{
by \\ David Gaukrodger, Senior Legal Advisor, OECD Investment Division
}

\begin{abstract}
Advanced systems of domestic corporate law generally apply a "no reflective loss" principle to shareholder claims. Shareholder claims are permitted for direct injury to shareholder rights (such as voting rights). But shareholders generally cannot bring claims for reflective loss incurred as a result of injury to "their" company (such as loss in value of shares). Only the directly-injured company can claim.

In contrast, shareholder claims for reflective loss have consistently been permitted under typical bilateral investment treaties (BITs) in recent years. This paper analyses investment treaty provisions relating to shareholder claims. It addresses (i) treaty regimes for shareholder recovery and company recovery of damages, including their consequences for investor protection and government liability; (ii) the interaction of reflective loss claims with treaty provisions that seek to limit multiple claims; and (iii) treaty provisions applicable to government objections to shareholder claims for reflective loss.
\end{abstract}

Approved by Pierre Poret, Deputy Director, OECD Directorate for Financial and Enterprise Affairs

JEL Classification: F21, F23, F53, F55, F63, G32, G34, G38, K23, K33, K41.

Key words: shareholders; stockholders; shareholder claims; shareholder rights; shareholder remedies; stockholder remedies; reflective loss; reflective injury; derivative action; derivative loss; derivative injury; consistency; consistency of arbitral decisions; judicial economy; concurrent claims; overlapping claims; related claims; settlement; corporate law; company law; creditors; creditors' rights; business corporations; separate legal personality; agency costs; investor-state dispute settlement; international arbitration; arbitrators; international economic law; comparative law; domestic impact of investment law; international arbitration; investment arbitration; foreign investment; international investment; international investment law; access to justice; level playing field; competitive neutrality; treaty shopping; international investment agreements; investment treaties; bilateral investment treaties 
TABLE OF CONTENTS

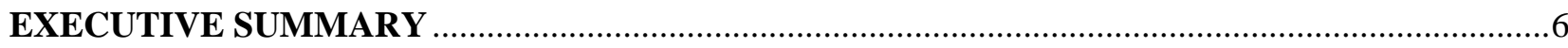

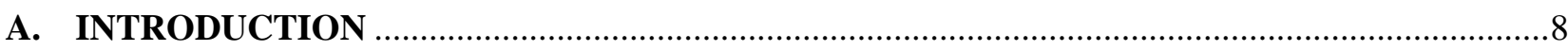

B. SHAREHOLDER CLAIM AND COMPANY RECOVERY REGIMES IN

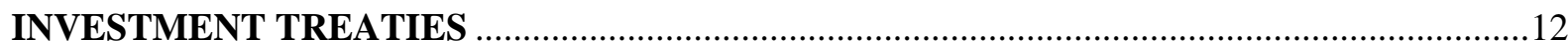

1. References in investment treaties to equity (share) interests in companies .....................................12

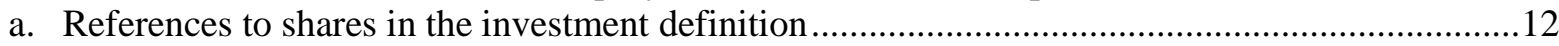

b. General absence of explicit attention to reflective loss or to the relevance of available

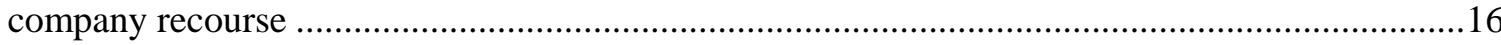

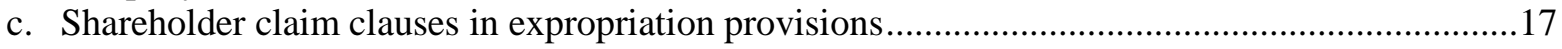

2. Indirect shareholdings and other indirect interests in companies................................................18

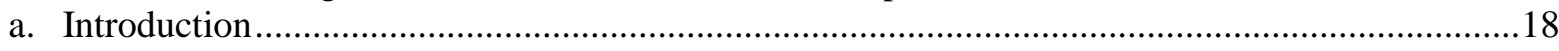

b. No domestic law equivalent to claims by indirect shareholders for reflective loss ........................19

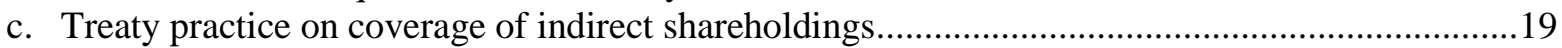

3. Regimes for recovery in ISDS by foreign-controlled domestic companies .......................................20

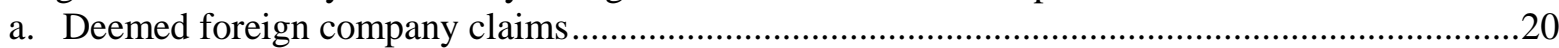

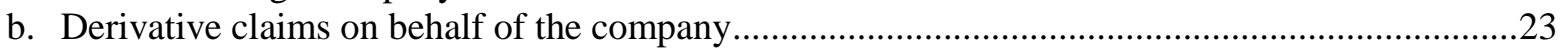

c. Express clarification of treatment of minority shareholders and reflective loss ..........................26

4. Beyond domestic companies: coverage of the complete corporate chain of shareholders .................26

5. "Foreign control" and other criteria for application of the company recovery regimes......................27
a. Treaty practice.

b. The ICSID criteria...

6. Consequences for investor protection of shareholder claim regimes and company recovery regimes in investment treaties.....

a. Investor protection under a company recovery regime without shareholder claims for reflective loss

b. Investor protection under treaties that permit shareholder claims for reflective loss by covered shareholders.

c. Investor protection analogous to traditional corporate law rules without a company recovery regime in ISDS

\section{INTERACTION OF SHAREHOLDER CLAIM AND COMPANY RECOVERY} REGIMES WITH SELECTED TREATY PROVISIONS

1. Claim-limiting provisions: Waiver, no u-turn, fork in the road, etc.

a. Claim-limiting provisions addressed only to the claimant entity may have little effectiveness if shareholder claims for reflective loss are permitted

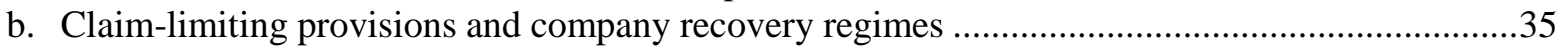

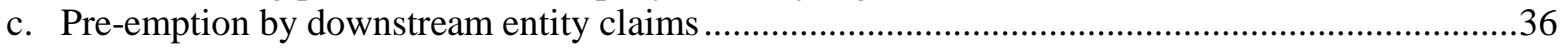

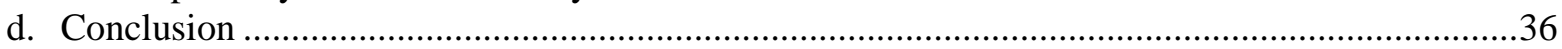

2. Consolidation of claims and joinder of related claims .....................................................................38 
3. Denial of benefits provisions.

a. Impact of denial of benefits provisions on the consistency risks created by shareholder claims for reflective loss

b. Impact of the availability of shareholder claims for reflective loss on denial of benefits provisions.....

4. Treaty requirements to use domestic courts and the availability of shareholder claims for reflective loss

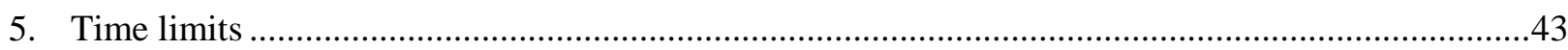

6. Explicit provisions for binding treaty party resolution of interpretive issues ...................................43

D. REGIMES FOR OBJECTIONS TO SHAREHOLDER CLAIMS .................................................44

1. Preliminary objections to shareholder claims ................................................................................4

a. Early dismissal of shareholder claims for reflective loss is frequently available under

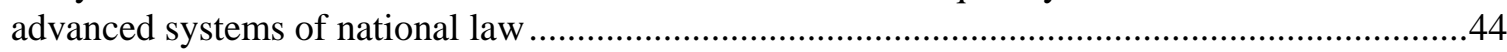

b. Parties and tribunals have taken varying approaches to consideration of shareholder claims

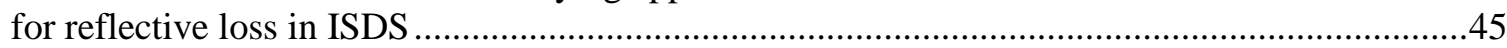

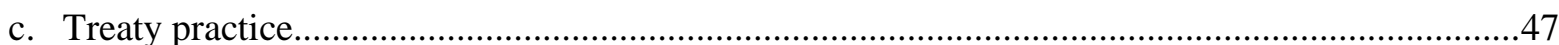

2. Treaty provisions governing review of decisions on shareholder claims for reflective loss in

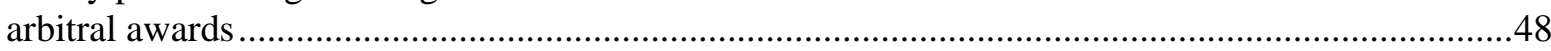

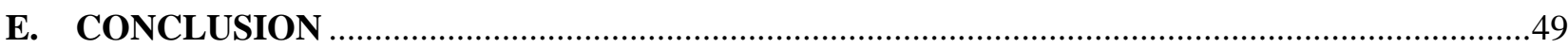

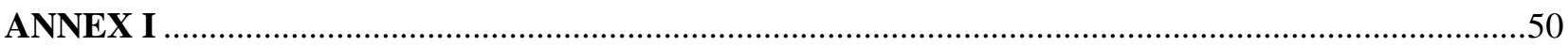

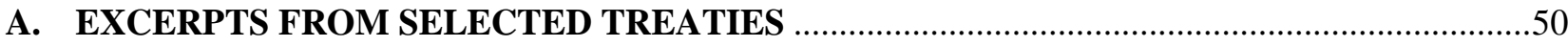

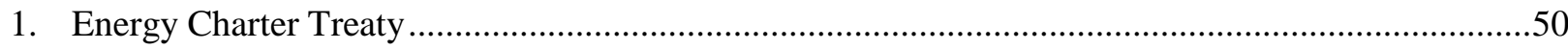

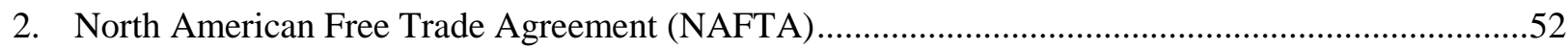

3. Agreement among the Government of Japan, the Government of the Republic of Korea and the Government of the People's Republic of China for the Promotion, Facilitation and Protection of Investment

4. Agreement between the Government of the United Mexican States and the Government of the People's Republic of China on the Promotion and Reciprocal Protection of Investments .................60

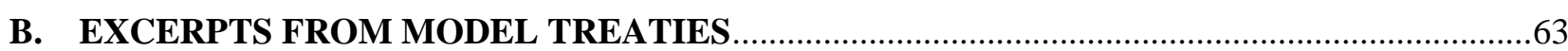

1. Netherlands 2004 Model Bilateral Investment Treaty ...............................................................63

2. South African Development Community 2012 Model Bilateral Investment Treaty Template

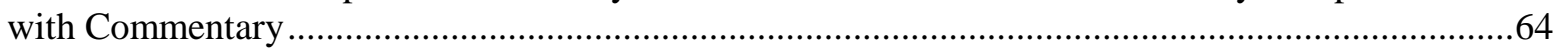

3. United States 2012 Model Bilateral Investment Treaty ................................................................68

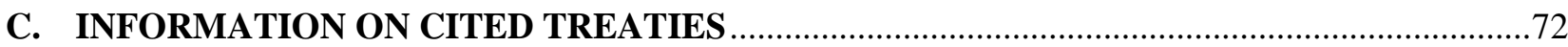




\section{EXECUTIVE SUMMARY}

The OECD-hosted Freedom of Investment (FOI) Roundtable recognised at its March 2013 meeting that, for a series of policy reasons, advanced systems of domestic corporate law generally apply a "no reflective loss" principle to shareholder claims: shareholders can claim for direct injury to their rights as a shareholder, but not for reflective loss incurred as a result of injury to the company. Only the directlyinjured company can recover the loss. In contrast, many investment arbitration tribunals in investor-state dispute settlement (ISDS) have found that shareholders are entitled to recover for reflective loss in ISDS under typical bilateral investment treaties (BITs).

Following on earlier work, this paper responds to Roundtable interest in more analysis of investment treaty practice relating to shareholder claims for reflective loss in ISDS. In light of varying government views about the advisability of permitting individual shareholder claims for recovery of reflective loss, the paper considers both how treaty clauses may address certain consistency risks that reflective loss claims may generate and how the availability of such claims may affect the operation of treaty provisions.

The first part of the paper considers treaty regimes for shareholder claims and company recovery. The ability of shareholders to claim in ISDS derives from the status of shares as an investment, which is expressly provided for in many investment treaties. It is generally accepted that shareholders can claim in ISDS for injury to their direct rights, such as the right to vote. Treaties generally do not explicitly address the question of shareholder claims for reflective loss, but, as noted, arbitral tribunals have consistently found that such claims are available under typical BITs. The paper notes that the availability of reflective loss claims greatly increases the practical impact of the frequent extension of treaty coverage to minority and indirect shareholders.

The ability of the injured company to obtain a remedy is of central importance in considering shareholder claims for reflective loss. This is because company recovery generally remedies reflective losses, both those of shareholders and those of others, including creditors. The paper addresses the two main regimes for recovery in ISDS by foreign-controlled domestic companies: (i) deeming the company to be foreign so that it can claim in ISDS on its own behalf; and (ii) permitting a derivative action in which a controlling foreign shareholder claims on behalf of the company. Some treaties further extend coverage beyond domestic companies. They cover the complete corporate chain of home-state controlled entities. The paper considers the consequences for investor protection of the different shareholder and company recovery regimes and the impact of the availability of claims for reflective loss.

The second part of the paper analyses how the different shareholder and company recovery regimes interact with selected treaty provisions relating to consistency issues. For example, some treaty provisions (waiver requirements, so-called "no u-turn" regimes or forks in the road) seek to limit overlapping claims, defined as multiple claims arising out of the same injury by shareholders and/or the company who have common ownership. Consolidation provisions typically regulate the possible joinder of overlapping or related claims in a single consolidated proceeding and provide for a fair selection process for arbitrators. Denial of benefits clauses may allow governments to limit the types of companies that can bring claims.

The impact of clauses of this type in controlling consistency risks generally varies greatly depending on whether or not reflective loss claims are permitted. Where reflective loss claims are permitted, these provisions are unlikely to provide effective legal controls on overlapping claims or multiple claims, or to ensure fair procedures for the orderly consolidation of related proceedings. Moreover, some treaty clauses, such as requirements to use domestic courts, may result in shareholder claims for reflective loss receiving 
preferential treatment over an ISDS claim by the injured company. This may increase the number of reflective loss claims.

The third part of the paper addresses regimes for objections to shareholder claims. Under domestic law, the courts regularly dismiss reflective loss claims early in a case. In ISDS, challenges to those claims fit uncomfortably into traditional limitations to preliminary objections in arbitration; they have been variously characterised as going to jurisdiction, admissibility or the merits. These uncertainties may explain in part the contrast between, on the one hand, the explicit policy basis for national court decisions barring claims for reflective loss in advanced systems of corporate law and, on the other hand, the narrow arbitral focus on the definition of investment and arbitral precedent in addressing shareholder claims for reflective loss in ISDS.

Some treaty provisions and the ICSID arbitration rules allow governments to require the tribunal to preliminarily rule on meritless claims. By broadening the grounds for preliminary challenges to include questions of law, they establish a procedural mechanism akin to the early dismissal mechanisms available in domestic law. They allow determination of the legal issues raised a claim for reflective loss at an early stage. Most treaties do not expressly address preliminary objections.

The lack of express attention to reflective loss in investment treaties extends to the scope of review of arbitral awards. Treaties have not expressly addressed the scope of review of decisions to allow or deny shareholder claims for reflective loss. Nor have they characterised the issue as jurisdictional or otherwise to define the scope of review under the general provisions of the ICSID and New York Conventions.

The regime for shareholder claims for reflective loss in ISDS and its impact on expectations about business corporations has not yet been subject to academic policy analysis akin to that applied to domestic corporate law rules in advanced jurisdictions. It is not clear that all governments have engaged in that analytical process in the case of their policy on claims for reflective loss under their investment treaties. Given the importance of specialised corporate law and investment law expertise for this policy analysis, there may be significant economies of scale and benefits in joint government attention to the issues raised by shareholder claims for reflective loss. 


\section{A. INTRODUCTION ${ }^{1}$}

The Freedom of Investment (FOI) Roundtable recognised at its March 2013 meeting that, for a series of policy reasons, advanced systems of domestic corporate law generally apply a "no reflective loss" principle to shareholder claims: shareholders can claim for direct injury to their rights as a shareholder, but not for reflective loss incurred as a result of injury to "their" company. ${ }^{2}$ Only the directly-injured company can recover the loss. ${ }^{3}$ In contrast, many ISDS arbitral tribunals have found that shareholders are entitled to recover for reflective loss in ISDS under typical BITs. ${ }^{4}$

The Investment Treaties as Corporate Law paper discussed by the Roundtable in March 2013 focused primarily on the policy issues relating to consistency that are raised by shareholder claims for reflective loss. ${ }^{5}$ It provided summary analysis of a small number of investment treaty provisions. These included the

This paper does not necessarily reflect the views of the OECD or of the governments that participate in the Roundtable, and it should not be construed as prejudging ongoing or future negotiations or disputes pertaining to international investment agreements.

The following economies are invited to participate in the Roundtable: Argentina, Australia, Austria, Belgium, Brazil, Bulgaria, Canada, Chile, China, Colombia, Costa Rica, Czech Republic, Denmark, Egypt, Estonia, Finland, France, Germany, Greece, Hungary, Iceland, India, Indonesia, Ireland, Israel, Italy, Japan, Jordan, Korea, Latvia, Lithuania, Luxembourg, Malaysia, Mexico, Morocco, Netherlands, New Zealand, Norway, Peru, Poland, Portugal, Romania, Russian Federation, Saudi Arabia, Slovakia, Slovenia, South Africa, Spain, Sweden, Switzerland, Tunisia, Turkey, United Kingdom, United States and the European Union. Participation typically varies somewhat depending on the issues being discussed.

See FOI Roundtable 18, Summary of discussion, p. 5 (March 2013). A preliminary framework for policy analysis of shareholder claims and consistency in ISDS is set forth in David Gaukrodger, Investment Treaties as Corporate Law: Shareholder Claims and Issues of Consistency ("Investment Treaties as Corporate Law"), OECD Working Paper on Investment 2013/3.

As outlined in Investment Treaties as Corporate Law, reflective loss refers to loss to shareholders caused by an injury to the company. Reflective loss, such as a decline in value of the shares, is generally distinguished from injury to a shareholder's direct rights, such the right to vote shares. See Investment Treaties as Corporate Law, pp. 13-14.

For analysis of domestic corporate law and general international law relevant to shareholder claims, see Investment Treaties as Corporate Law, pp. 15-24.

In Investment Treaties as Corporate Law, the following simplifying assumptions are made about shareholder claims for reflective loss in ISDS under typical BITs for purposes of policy analysis: (i) both direct and indirect shareholders can bring ISDS claims; (ii) both controlling and minority shareholders can bring ISDS claims; (iii) shareholders can bring ISDS claims for both direct and reflective loss; (iv) shareholders have an autonomous right to claim in ISDS regardless of company recourse; and (v) company nationality (including the nationality of shareholders who are companies) is determined by the state of incorporation without any requirement of a "genuine link". The same assumptions generally apply herein except where they are relaxed for analytical purposes. This paper takes no position on whether the interpretations set forth above are correct with regard to BITs in general or any particular treaty.

For the policy issues relating to consistency raised by SRL including as identified in domestic corporate law cases and commentary, see generally Investment Treaties as Corporate Law, pp. 32-51. They include a greater likelihood of multiple high-cost claims for the same injury; obstacles to settlement; potentially inconsistent results; expanded scope for treaty shopping; injury to creditors generating a risk of additional 
definition of investment under a typical BIT and certain provisions allowing for recovery by foreigncontrolled companies in ISDS. Roundtable participants expressed interest in more analysis of treaty practice relevant to individual shareholder claims for reflective loss (SRL) and the policy issues they raise, and this paper responds to that interest. ${ }^{6}$

Preliminary discussions suggest that Roundtable governments may have different views about whether it is advisable to permit SRL in some or all of their investment treaties. ${ }^{7}$ Some governments may favour broad availability of SRL in ISDS. Others may favour a general bar on SRL in ISDS as under domestic law. One suggested that its preference for a general bar on SRL as opposed to current ISDS law provided support for the application of a national law approach. Others have excluded SRL from their model treaty (and make available a derivative action in which the company, not the shareholder, recovers the damages). Some governments may want to limit SRL in specific contexts, or adopt different approaches in different treaties. Further discussion and analysis may refine government views about their individual and collective goals relating to SRL in ISDS.

This paper seeks to take account of this diversity of government views about SRL. ${ }^{8}$ It considers whether the selected investment treaty clauses effectively address certain consistency risks that SRL may generate. It also analyses how the availability or not of SRL may affect the operation of the treaty provisions.

The analysis focuses on a limited number of treaties, including some multilateral treaties. ${ }^{9}$ Governments are encouraged to provide additional examples of relevant treaty practices and experience. As in previous Roundtable work, comparative law sources are analysed, in particular to identify possible issues and specificities in ISDS.

The paper is divided into three parts. The first part examines the investment treaty provisions that allow for shareholder and company recovery. ${ }^{10}$ It first reviews the provisions that allow shareholders to

claims; the need for complex and expensive efforts to allocate the reflective losses between corporate constituencies; risks of double recovery; and risks of a single shareholder having "two bites at the apple".

See FOI Roundtable 18, Summary of discussion, p. 8. The Roundtable also expressed interest in additional policy analysis of shareholder claims for reflective loss from a corporate law perspective, including their impact on investment, creditors and non-claiming shareholders. See Eilís Ferran, Reflective Loss (presentation to FOI Roundtable, 16 October 2013); David Gaukrodger, Investment treaties and shareholder claims for reflective loss: Insights from advanced systems of corporate law, OECD Working Paper on Investment 2014/02.

See FOI Roundtable 18, Summary of discussion, pp. 7-8, for a general summary of views.

Given the policy and procedural issues posed by SRL, it is noteworthy that most investment treaties contain few if any provisions addressing SRL. For some governments, the sparse attention may reflect confidence in the ability of arbitrators to exercise their discretion and develop a coherent regime over time. Other governments may consider that the lack of attention to SRL reflects that SRL was not contemplated by the treaty drafters. These views (and other possible views) are noted here as an introductory matter; for readability, they are not repeated in the text below. The paper does not address the correctness or reasonableness of arbitral interpretation with regard to the availability of SRL under any treaty or treaties in general.

9 Excerpts from selected treaties are reproduced in Annex I.A.

As in Investment Treaties as Corporate Law, for purposes of policy discussion only, some general meanings are given to certain terms herein. References to shareholders refer generally to shareholders 
make claims for individual recovery. These include references to shares in the definition of investment and provisions addressing indirect shareholders. The paper notes the general absence of explicit attention to reflective loss or to the relevance to SRL of company recourse.

Recourse available to the company is generally considered to be of central importance in evaluating shareholder claims because company recovery of its losses generally takes care of shareholders' reflective losses. The analysis reviews treaty regimes for recovery in ISDS by domestic companies that are foreigncontrolled. ${ }^{11}$ These are of two main types : (i) deeming the company to be foreign so that it can claim in ISDS on its own behalf; and (ii) permitting a derivative action in which a controlling foreign shareholder claims on behalf of the company. Some treaties further extend treaty coverage beyond domestic companies to include complete corporate chains of home-state controlled entities.

Treaties use varying criteria to govern access to company recovery. They typically involve different approaches to the notion of foreign control. In light of interest expressed at Roundtable 18 in the impact of SRL on investors, the paper then preliminarily considers, from the perspective of investor protection and incentives, the interaction of the availability of SRL with the different shareholder and company recovery regimes.

The second part of the paper analyses how the shareholder and company recovery regimes interact with selected treaty provisions relating to consistency issues. SRL can give rise to two types of multiple claims arising out of the same injury to a company: (i) "overlapping" claims -- claims by shareholders and/or the company who have common ownership; and (ii) "related" claims -- claims by unrelated shareholders of the same company.

A first category of treaty provisions seeks to limit overlapping claims arising out of the same events (which can give the same beneficial investor "two bites at the apple"). The provisions take different forms including waiver requirements, so-called "no u-turn" regimes or fork in the road clauses. Referred to generically herein as "claim-limiting provisions", they may apply only to overlapping claims by the same party, or they may extend to overlapping claims by certain related parties. The analysis then turns to consolidation provisions, which regulate the possible joinder of overlapping or related claims in a single consolidated proceeding; denial of benefits clauses, which allow the government to limit the types of companies that can bring claims; requirements to use domestic courts; time limits on the bringing of claims; and provisions for binding party interpretation of treaties.

The third part addresses regimes for objections to SRL both in the initial arbitration and in the context of post-award review. Advanced systems of domestic law frequently allow for the early dismissal of SRL.

covered by an investment treaty; where clarification is needed, covered and non-covered shareholders are distinguished. Shareholder refers generally to a direct or indirect shareholder.

References to the "company" refer to the company in which the shareholder owns shares (directly or indirectly). References to the "operating company" generally refer to the company that is active and that incurs the direct loss due to government misconduct. Domestic company refers to a company incorporated in the host State.

No position is taken with regard to the question of whether any such assumptions, interpretations or definitions are applicable with regard to BITs in general or any particular treaty.

The general term "foreign-controlled" is used here for convenience. As discussed below, treaties vary in the precise standards used to govern access to the company recovery regimes. The varying criteria are described below in section B.5 on "Foreign control' and other criteria for application of the company recovery regimes". 
The procedural treatment of SRL in ISDS has varied (although, as noted, the general outcomes in terms of permitting SRL under typical BITs have been generally consistent). While most treaties do not address preliminary objections, some treaty provisions and the ICSID arbitration rules allow governments to require the tribunal to preliminarily rule on meritless claims. By broadening the grounds for preliminary challenges to include questions of law, they establish a procedural mechanism akin to the early dismissal mechanisms available in domestic law and allow determination of the legal issues raised by a challenge to SRL at an early stage. The paper notes that the lack of express attention to SRL in most investment treaties extends to the scope of review of arbitral decisions to allow or deny SRL under the treaty. 


\section{B. SHAREHOLDER CLAIM AND COMPANY RECOVERY REGIMES IN INVESTMENT TREATIES}

\section{References in investment treaties to equity (share) interests in companies}

The availability and price of equity and debt financing are key determinants to the amount of investment by companies and their investment decisions. Companies can obtain equity and debt financing in many ways. Investment treaties frequently contain references to shares, debt interests and other interests in companies in their investment definitions.

This section briefly reviews sample treaty provisions relating to equity (share) interests in companies. ${ }^{12}$ As noted in Investment Treaties as Corporate Law, ISDS tribunals have attributed great significance, in terms of modifying corporate law principles on SRL, to the inclusion of shares in the investment definition of investment treaties. ${ }^{13}$

\section{a. $\quad$ References to shares in the investment definition}

As noted in Investment Treaties as Corporate Law, the only reference to shares in many investment treaties is a clause that clarifies that shares are assets that qualify as an investment. Shares are often covered in general terms without any express carve-outs for particular types of equity instruments. For example, the recent China-Japan-Korea treaty refers to "shares, stocks or other forms of equity participation in an enterprise, including rights therefrom". ${ }^{14}$ The Energy Charter Treaty (ECT) expressly includes "shares, stock, or other forms of equity participation in a company or business enterprise". ${ }^{15}$ NAFTA refers generally to equity securities. "Equity or debt securities" are broadly defined as including "voting and non-voting shares, bonds, convertible debentures, stock options and warrants". ${ }^{16}$

Treaties appear rarely to contain minimum size, value or percentage requirements for share interests in the investment definition. It would appear that minority and small shareholding interests are thus frequently covered as investments, sometimes expressly. ${ }^{17}$

Some treaties exclude portfolio investments. For example, the South African Development Community (SADC) 2012 Model Bilateral Investment Treaty Template expressly excludes portfolio investment in each of its three proposed variants of an investment definition. ${ }^{18}$ Portfolio investment is

\footnotetext{
$12 \quad$ Provisions addressing debt are briefly addressed below in Box 1.

13 See Investment Treaties as Corporate Law, pp. 25-31.

China-Japan-Korea art. 1(1)(b). For convenience, treaties are generally referred to by reference solely to the names of the Contracting Parties, listed in alphabetical order. Annex 1.C provides the full names of cited treaties.

15 ECT art. I(6)(b).

$16 \quad$ NAFTA art. 1139.

17 See France 2006 Model BIT, art. 1(1)(b) (covering "les actions, primes d'émission et autres formes de participation, même minoritaires ou indirectes, aux sociétés ...")

See SADC 2012 Model BIT Template, pp. 9-11.
} 
defined as less than $10 \%$ share ownership or investment that "does not give the portfolio investor the possibility to exercise effective management or influence on the management of the investment."19

The China-Germany treaty covers shares in general terms in its article 1 definition of investment. A Protocol to the treaty, however, suggests some possible limitations on coverage of certain types of share ownership based on, inter alia, whether a shareholder exercises effective influence over the company. ${ }^{20}$

The impact of coverage of minority shareholders differs depending on whether SRL are available or not. Protection of minority shareholders' direct rights (as understood under general corporate law and general international law) extends to a limited range of specific shareholders rights, such as the right to vote and to receive any declared dividends. ${ }^{21}$ Shareholder's direct rights are often also considered to include protection against expropriation of company assets. For example, in GAMI, the US and Mexico affirmed that "[a] classic example of direct loss or damage suffered by shareholders is when the host State wrongfully expropriates the shareholders' ownership interests, whether directly through an expropriation of the shares, or indirectly by expropriating the corporation as a whole." ${ }^{22}$

Id., p. 11.

The 1998 Framework Agreement on the ASEAN Investment Area (AIA) explicitly excluded portfolio investment, but the more recent ASEAN Comprehensive Investment Agreement (ACIA), which supersedes the AIA, is not similarly restricted. It expressly extends protection to "shares, stocks, bonds and debentures and any other forms of participation in a juridical person and rights or interests derived therefrom". Assets must have the characteristics of an investment and, where applicable, may be subject to prior written approval. See ACIA, art. 4(a),(c). ACIA entered in force in April 2012 and AIA was terminated. See ACIA, art. 47(1).

See China-Germany, Protocol to the Agreement between the People's Republic of China and the Federal Republic of Germany on the Encouragement and Reciprocal Protection of Investments art. 1(1) ("For the avoidance of doubt, the Contracting Parties agree that investments as defined in Article 1 are those made for the purpose of establishing lasting economic relations in connection with an enterprise, especially those which allow to exercise effective influence in its management.")

See Investment Treaties as Corporate Law, pp. 13-14. Similar principles apply in general international law. For recent discussion and application of the distinction between direct and reflective loss rights in the international sphere, see Case Concerning Ahmadou Sadio Diallo (Republic of Guinea v. Democratic Republic of the Congo), Preliminary Objections, Judgment (2007) ICJ Rep. 582, §§ $62-67$ (distinguishing between admissible claims based on direct rights of shareholder and inadmissible claims based on reflective loss); Case Concerning Ahmadou Sadio Diallo (Republic of Guinea v. Democratic Republic of the Congo), Merits, Judgment (2010) ICJ Rep. 639, §§ 155-57 (reaffirming the distinction).

GAMI v. Mexico, Submission of the United States (non-disputing party) (30 June 2003) § 9; id, Escrito de Contestación of Mexico, p. 63 n.158 (24 Nov. 2003) (quoting and agreeing with US submission). See also International Thunderbird v. Mexico, Submission of the United States (non-disputing party) (21 May 2004) $\S \S 13-14$ ("Where an investor that is a shareholder in a locally-organized enterprise suffers a direct injury to its interest in the enterprise - for example, where the investor is denied its right to a declared dividend or its right to vote its shares - the investor has standing to bring a claim under [NAFTA] Article 1116 in accordance with customary international law principles. Finally, Article 1116 provides a right of action for claims by the investor that the entire enterprise has been expropriated and, therefore, its interest in the enterprise has been taken without compensation as well.").

The inclusion of expropriation of the entire enterprise as a direct injury for shareholders is generally assumed herein. Some treaties clarify or provide that shareholders may claim for expropriation where the company's assets are expropriated. (See below section B.1.c, Shareholder claim clauses in expropriation provisions). Expropriation of a debtor company leading to default on foreign loans may similarly constitute 
While shareholders' direct rights are limited to a narrow range of direct losses and expropriation, the availability of SRL allows minority shareholders to claim for the full range of injury to the company which can include, for example, injury caused by a failure to provide fair and equitable treatment.

direct injury to creditors. See NAFTA, art. 1110(8) (contemplating possibility of expropriation of creditor through injury to debtor company affecting creditors). 


\section{Box 1: References to debt in the investment definition ${ }^{23}$}

Many investment treaties refer expressly to debt in their investment definition. Some treaties refer to debt in general terms in their enumerated examples of investments. For example, in addition to referring generally to "all assets", the China-Japan-Korea treaty (art. $1(1)(c))$ expressly covers "bonds, debentures, loans and other forms of debt, including rights derived therefrom". The ECT supplements its all assets definition with a specific reference (in art. I(6)(b)) to "bonds and other debt of a company or business enterprise".

The inclusion of debt interests in companies is sometimes more qualified than for shares. Some treaties exclude some debt based on its duration or term. For example, NAFTA (art. 1139) only covers debt securities with an original maturity of over three years (or debt securities issued between affiliated enterprises); the same duration-based limits apply to loans.

The US 2012 Model BIT has a more flexible approach, but takes account of the duration of the debt. A specific clause in the article 1 definition of investment refers generally to "bonds, debentures, other debt instruments, and loans". However, an interpretive footnote makes clear that not all debt constitutes an investment: "Some forms of debt, such as bonds, debentures, and long-term notes, are more likely to have the characteristics of an investment, while other forms of debt, such as claims to payment that are immediately due and result from the sale of goods or services, are less likely to have such characteristics." (The general characteristics of an investment are defined as follows in the introduction to the section: "every asset that an investor owns or controls, directly or indirectly, that has the characteristics of an investment, including such characteristics as the commitment of capital or other resources, the expectation of gain or profit, or the assumption of risk".)

ASEAN-China (art. 1(1)(d)(ii)) supplements its all assets definition with a specific reference to "debentures of juridical persons or interests in the property of such juridical persons". Secured debt involving the taking of property interests as security would appear to be explicitly covered. The coverage of other debt could depend on, among other things, the breadth of the notion of debenture and/or on the residual application of the "all assets" definition. Chile-Japan (art. 105(1)(h)(iii)) similarly supplements an all assets definition with an express reference to "bonds, debentures, loans and other debt instruments".

Other provisions may exclude certain types of debt, such as trade financing. NAFTA excludes credit in connection with a commercial transaction, such as trade financing (unless it meets the requirement for a loan). Debt issued by SOEs and/or governments is expressly excluded in a number of treaties. For example, NAFTA (art. 1139) excludes debt of and loans to state enterprises. Chile-Japan (art. 105(1)(h)(iii)) excludes "debt instrument[s] of a Party or of a state enterprise".

Other treaties do not refer to debt as such or contain arguably limited references, but contain other broadly-worded clauses. For example, the 2008 German Model BIT (art. 1(1)(c)) contains an all assets definition and broad clauses referring to "claims to money which has been used to create an economic value or claims to any performance having an economic value", but does not expressly address debt as such. The older 1992 Japan-Turkey treaty (art. $1(1)(a),(b))$ supplements an all assets definition with an explicit reference, with regard to interests in companies, only to shares and "other types of holding of companies". However, it also refers to "claims to money or to any performance under contract having a financial value which are associated with investment".

As for shares, treaties have generally not expressly addressed the issue of creditor rights to recover reflective loss. 


\section{b. General absence of explicit attention to reflective loss or to the relevance of available company recourse}

Governments appear to have only very rarely explicitly addressed the issue of reflective loss or the scope of shareholder rights in investment treaties; treaties simply refer to shares without further elaboration. ${ }^{24}$ As noted in Investment Treaties as Corporate Law, the no reflective loss principle in domestic law is primarily a case-law principle. There does not appear to be any existing domestic law setting forth the principle as a matter of general corporate law; the issue is generally left to the courts. Many advanced corporate law jurisdictions have lengthy company law statutes, and many now include derivative actions allowing for company recovery at the instigation of a shareholder. But the statutes do not appear to address the prohibition on SRL. The closest existing equivalent to a statutory scheme is the privately-produced, non-binding American Law Institute Principles of Corporate Governance. ${ }^{25}$

There is a similar absence of attention to the issue of company recourse in typical BITs. As noted in Investment Treaties as Corporate Law, the bar on SRL under domestic law is closely linked to the availability of a company claim or company recovery through a derivative action. SRL are excluded because it is preferable to allow the company to decide whether to claim and to recover the loss it has incurred. Investment treaties have not expressly linked the availability of SRL to the absence of, or government interference with, effective company recourse in the domestic courts. ${ }^{26}$ ISDS arbitrators have found that SRL in ISDS are autonomous from company recourse in the domestic courts and in ISDS. ${ }^{27}$

Treaties have also not explicitly required consideration of the possible injury to company creditors, non-claimant shareholders or the respondent in deciding on the availability of SRL, issues considered by many national courts in deciding on SRL. ${ }^{28}$

China-Mexico is one recent exception: the parties expressly recognise that the treaty provisions only allow minority shareholders to make claims for direct loss or damage. See China-Mexico art. 13(8) and further below. American Law Institute, Principles of Corporate Governance, § 7.01 (1994 \& 2012 Supp.).

Some commentators have suggested that SRL should be restricted to, inter alia, cases where the company's recourse in the domestic courts is impaired. See Zachary Douglas, The International Law of Investment Claims (2009), p. 397 (suggesting that the availability of SRL in ISDS should be restricted, but that, under certain conditions, SRL should be available where the company has been deprived of a remedy to redress its injury or of the capacity to sue, or has been subjected to a denial of justice in the domestic courts).

Investment Treaties as Corporate Law, pp. 27-28.

Compare American Law Institute, Principles of Corporate Governance, § 7.01 (1994 \& 2012 Supp.) (providing for a general bar on SRL, but suggesting a possible narrow exception under certain conditions providing the court finds that "to do so will not (i) unfairly expose the corporation or the defendants to a multiplicity of actions, (ii) materially prejudice the interests of creditors of the corporation, or (iii) interfere with a fair distribution of the recovery among all interested persons".); Douglas, pp. 455 et seq. (suggesting incorporation of these considerations into the treatment of SRL in ISDS). See also Eilís Ferran, Reflective Loss (presentation to FOI Roundtable, 16 October 2013); David Gaukrodger, Investment treaties and shareholder claims for reflective loss: Insights from advanced systems of corporate law, OECD Working Paper on Investment 2014/02. 


\section{Issues for discussion}

- Because the general bar on SRL under domestic law is generally found in case law, it may be difficult to articulate the rule, as well as possible exceptions, in statutory or treaty form. There are few examples of statutory treatment of SRL. Are the rules on SRL in your country found in a statute or in case law?

- Assuming the availability of SRL is established, does the investment definition provide a sufficient basis to resolve the various issues raised by SRL? Does the language provide a basis for limits on SRL?

- Should there be limits on SRL? Of what kind? Why?

- What explains the lack of attention to SRL in treaty language in your view?

\section{c. $\quad$ Shareholder claim clauses in expropriation provisions}

A few treaties specifically provide or clarify that shareholders may claim for expropriation if company assets are expropriated. For example, article 13(3) of the ECT clarifies that shareholders can claim where company assets are expropriated. ${ }^{29}$ The Russian Federation-UK and the Argentina-Germany BITs also provides specific protection to allow shareholder claims in the event of expropriation of the assets of the company. ${ }^{30}$

Various interpretations of these clauses are possible. First, some governments have argued that specific provisions allowing shareholder claims in the expropriation context reflect an understanding that shareholder claims are otherwise generally barred. Second, the provisions providing or clarifying shareholders rights with regard to expropriation could be understood as providing or clarifying that expropriation of company assets constitutes direct injury for shareholders, a view held by the US and Mexico as noted above; shareholders' other direct rights would also remain protected. A third interpretation finds that this type of clause has been superseded by the general evolution of arbitral case law finding SRL to be generally available. Tribunals have rejected the first interpretation and appear to have favoured the third interpretation to date, finding SRL to be generally available notwithstanding the specific clause addressing shareholder rights relating to expropriation. ${ }^{31}$ Contracting Party expropriates the assets of a company or enterprise in its Area in which an Investor of any other Contracting Party has an Investment, including through the ownership of shares.”).

See Russian Federation-UK art. 5(2) ("Where a Contracting Party expropriates the assets of a company or enterprise which is incorporated or constituted under the law in force in any part of its own territory, and in which investors of the other Contracting Party have a shareholding, the [expropriation] provisions ... shall apply.")

The Argentina-Germany treaty contains an article 4 which provides protection against measures amounting to an expropriation. A Protocol to the treaty provides that shareholders have a right to be compensated where they suffer harm due to expropriation of a company. See Argentina-Germany ad. 4 ("The right to be compensated also exists when measures defined in Article 4 are adopted in respect of a company where the investment has been made and as a result of such measures the investment is severely prejudiced.")

See Siemens A.G. v. Argentine Republic, Decision on Jurisdiction, ICSID (2004) $§ 140$ ("there is no merit in the allegation that the provision for indirect [shareholder] claims in Article 4 and the corresponding provision of the Protocol are an indication that such claims are not permitted under other provisions of the Treaty"); Hochtief A.G. v. Argentine Republic, Decision on Jurisdiction, ICSID (2011)§§ 115-16. In 


\section{Indirect shareholdings and other indirect interests in companies}

\section{a. Introduction}

Direct shareholders are the immediate, legal shareholders of the company. Indirect shareholders hold shares in an intermediate company that is a (direct or indirect) shareholder of the operating company. The indirect shareholder may be the top-level shareholder or an intermediate-level entity.

As noted above, many investment treaties cover indirect shareholders. As in the case of minority shareholders, the practical impact of extending treaty coverage to indirect shareholders depends to a significant extent on whether SRL are available. In the absence of SRL, indirect shareholder claims would be limited to claims for direct injury which are likely to be rare. Expropriation of the company can be considered to cause direct injury to both direct and indirect shareholders. But other types of direct injury are rare for direct shareholders and may be still rarer for indirect shareholders because they likely have at most only a limited range of direct rights.

In contrast, when combined with the availability of SRL, treaty coverage of indirect (and minority) shareholders substantially expands the protection of foreign shareholders. It multiplies the number of companies whose injuries may be the object of an ISDS claim. Many domestic companies now have substantial foreign shareholder interests (direct or indirect); these can include both relatively passive investors such as pension funds and mutual funds and more activist investors such as hedge funds. The domestic companies themselves are likely limited to non-pecuniary remedies under domestic administrative law; claims by their domestic controlling or minority shareholders are in addition generally barred by the no reflective loss rule. ${ }^{32}$

With coverage of minority and indirect shareholders and the availability of SRL, covered foreign shareholders of these domestic companies have access to ISDS to claim damages for injury to the company. The availability of SRL for indirect and minority foreign shareholders also accentuates the differences in treatment between foreign and domestic shareholders and may have a broader impact on capital markets: rather than being preferentially protected primarily for expropriation (of themselves or of the company), foreign shareholders are specially protected for the full range of treaty protection in the event of injury to the company. ${ }^{33}$

RosInvestCo UK Ltd v. The Russian Federation, Award, SCC (2010), the tribunal did not need to decide the issue because the case involved an expropriation and the shareholder's claim was covered by the specific art. 5(2) provision in the Russian Federation-UK treaty. The tribunal nonetheless stated that it considered that recent arbitral interpretation of various treaties has resolved the shareholder claim issue for modern investment treaty arbitration generally regardless of provisions like art. 5(2). Id., § 608.

See FOI Roundtable Progress Report on ISDS (Dec. 2012), p. 10; David Gaukrodger \& Kathryn Gordon, Investor-State Dispute Settlement: A Scoping Paper for the Investment Policy Community (Dec. 2012) ("ISDS Scoping Paper"), pp. 25-27 \& Annex 4 (except for cases of expropriation, damages remedies for investors are rare in advanced national systems of administrative law). Foreign-controlled domestic companies may have access to ISDS. (See below section B.3 on Regimes for recovery in ISDS by foreigncontrolled domestic companies).

Because the company is domestic and may have majority domestic share ownership, it is unclear whether the minority foreign shareholders can claim for reflective loss due to injury to the company based on a violation of national treatment. However, other protections, such as the requirement of fair and equitable treatment, may form the basis of SRL. 
Coverage of indirect shareholders is a different issue than the availability of SRL. Changes to each have different consequences. For example, exclusion of indirect shareholders from the investment definition would (i) limit but not exclude SRL because direct shareholders could still bring SRL; and (ii) have effects beyond SRL because it would eliminate indirect shareholders' protection from direct injury such as expropriation.

\section{b. $\quad$ No domestic law equivalent to claims by indirect shareholders for reflective loss}

It appears hard to find an equivalent in domestic corporate law to a SRL by an indirect shareholder. Because claims by direct shareholders for reflective loss are generally rejected in domestic law, a claim by an indirect shareholder would appear to be unlikely. It appears that there are few if any such claims in advanced national systems of corporate law. ${ }^{34}$

Some advanced corporate law jurisdictions do allow an indirect shareholder to bring a "double" or "multiple" derivative claim. Derivative claims, however, are not SRL. In derivative claims, the company recovers the damages, not the (indirect or direct) shareholder. Other claims for the same injury are barred and all corporate stakeholders benefit rather than a single shareholder. (See below section B.3.b on derivative claims)

\section{$c$.}

Treaty practice on coverage of indirect shareholdings

A number of recent treaties address indirectly-held investments generally. For example, the reference to the coverage of indirect investments can be contained in the general introduction of the investment definition applicable to all assets, rather than in the specific sections addressing interests in companies. It applies to shares as investments and may also include other indirectly owned or controlled investments, including debt. ${ }^{35}$ Other treaties expressly refer to indirect shareholdings rather than generally to indirect investments. ${ }^{36}$

Other treaties do not expressly address the issue of indirect ownership or control. For example, the ACIA covers "every kind of asset" and provides an illustrative list, but does not specifically refer to indirect holdings. ${ }^{37}$ Under some treaties of this type, arbitrators have found that indirect shareholdings are covered (including for purposes of reflective loss) unless they are expressly excluded. ${ }^{38}$

\section{Issues for discussion}

\footnotetext{
$34 \quad$ Creditor protection issues raised by SRL are likely more acute with regard to indirect than direct shareholders. Changes in indirect shareholder ownership of a company are more difficult to monitor than change in direct ownership. Changes can occur at any level of the corporate chain (or by adding new levels). Creditors are likely to be unable to monitor at reasonable cost the evolving composition of the class of indirect shareholders, the evolution of ISDS coverage of the class, or the likelihood of SRL.

The ECT refers in part to "every kind of asset, owned or controlled directly or indirectly by an Investor". ECT art. I(6)(b); China-Japan-Korea art. 1(1) ("every kind of asset that an investor owns or controls, directly or indirectly ..."); US 2012 Model art. 1 ("every asset that an investor owns or controls, directly or indirectly ..."); Argentina-US art. I(1)(a)(ii).

Canada-Hungary art. I(b)(ii).

See ACIA art.4(c); Japan-Turkey art.1(1); Canada-Poland, art. I(b) .

See, e.g., Siemens A.G. v. Argentine Republic, ICSID, Decision on Jurisdiction (2004), $\S 137$ et seq.
} 
- Do you agree that the practical impact of extending treaty protection to minority and indirect foreign shareholders differs considerably depending on whether SRL are available?

- In your view, what are the costs and benefits of protecting covered minority shareholders generally for injury to the company rather than only for injury to the shareholder's direct rights (including protection from expropriation)?

\section{Regimes for recovery in ISDS by foreign-controlled domestic companies}

There are two principal types of regimes for recovery of damages in ISDS by foreign-controlled ${ }^{39}$ domestic companies: (i) deeming the company to be foreign so that it can claim in ISDS on its own behalf; and (ii) permitting a derivative action in which a controlling foreign shareholder claims on behalf of the company. ${ }^{40}$ Both regimes result in recovery for the domestic company, not for the individual shareholder. For that reason, they are referred to collectively herein as company recovery regimes.

The availability of SRL largely determines the practical importance of domestic company recovery regimes. If SRL are available, the regimes may be unlikely to be used because shareholders will prefer to bring SRL. In contrast, if SRL are limited or excluded, company recovery regimes will take on much greater importance. As noted in Investment Treaties as Corporate Law, it appears that the widespread acceptance of SRL by arbitrators has led to the disuse of company recovery mechanisms: economic incentives are likely to favour SRL rather than claims for company recovery if the former are available under applicable law. ${ }^{41}$

\section{a. Deemed foreign company claims}

Following some examples of treaty practice, two issues regarding deemed company claim regimes are briefly addressed here: (i) the risk of host government "neutralisation" of the company so that it cannot bring the case; and (ii) coverage of claims in non-ICSID fora.

\section{i. $\quad$ Treaty practice}

There are several approaches in treaty practice to deeming foreign-controlled domestic companies to be foreign. One approach is through the general criteria for corporate nationality. For example, a treaty can include general criteria attributing nationality based on either (i) incorporation; or (ii) control. The Netherlands' treaties are the best known example of this approach. Under the Netherlands 2004 Model BIT, a company incorporated in the Netherlands is Dutch. Any company controlled by a Netherlandsincorporated company is also Dutch for purposes of the treaty, regardless of where it is incorporated or

As noted above, the general term "foreign-controlled" is used here for convenience. As discussed below in section B.5, treaties vary in the precise standards used to govern access to the company recovery regimes.

In Investment Treaties as Corporate Law, deemed company claim mechanisms were addressed by reference to ICSID art. 25(2)(b). See Investment Treaties as Corporate Law, pp. 56-58. This section focuses more generally on regimes for domestic company claims set forth in investment treaties. For ICSID cases, both the investment treaty criteria and the ICSID criteria must be satisfied.

See Investment Treaties as Corporate Law, pp. 57-58; Douglas, The International Law of Investment Claims (2009), p. 452 ("It is difficult to imagine why a shareholder would elect to bring a claim for the account of its company if it had the option of bypassing the company altogether. The company might be liable to pay creditors, local taxes and discharge other obligations before distributing the residual amount of any damages recovered to the shareholders.") 
located. Together, the two clauses make a Netherlands-controlled domestic company Dutch for purposes of the treaty. ${ }^{42}$ (See also below section B.4 on "Beyond domestic companies: coverage of the complete corporate chain of shareholders").

A separate clause can also deem domestic companies to be foreign. For example, art. 8(2) of the 2008 UK 2005 Model BIT states as follows:

A company which is incorporated or constituted under the law in force in the territory of one Contracting Party and in which before such a dispute arises the majority of shares are owned by nationals or companies of the other Contracting Party shall in accordance with Article 25(2)(b) of the [ICSID] Convention be treated for the purposes of the Convention as a company of the other Contracting Party.

As noted in the ISDS treaty survey, approximately $20 \%$ of the treaties in the sample contain deemed company regimes. ${ }^{43}$

\section{ii. $\quad$ Neutralisation of the company by the host government}

Deemed company regimes rely on the company itself having access to ISDS. Potential host government interference with the access of a deemed company to ISDS may be a concern under this regime. $^{44}$

The requirement of control in deemed company regimes means that the foreign controlling shareholder can normally ensure that the deemed company conducts the ISDS litigation as appropriate. The international nature of ISDS arbitration proceedings, which typically take place outside the host country, also limit the possibilities for neutralisation. However, in some cases, a host government's misconduct may neutralise the domestic company so that it cannot even bring or conduct an ISDS case.

Interference with the controlling shareholder's right to vote shares or elect directors to manage the company with respect to prosecuting the claim could constitute direct injury and permit an individual shareholder claim for its direct loss. SRL made available on a showing of company neutralisation would allow an individual covered shareholder (rather than all corporate stakeholders) to avoid the consequences of neutralisation. ${ }^{45}$ In some cases, the neutralisation could amount to an expropriation causing direct injury to shareholders.

42 See Netherlands 2004 Model BIT, art. 1(b)(ii),(iii). The Mercosur Protocol of Colonia for the Reciprocal Promotion and Protection of provides that juridical persons that are effectively controlled, directly or indirectly, by nationals of other Contracting States have the status of Investors and can bring claims under the treaty. This is similar to the Dutch approach in some respects. However, it differs significantly because it expressly requires "effective control" by a home state entity. This likely requires the actual exercise of powers or direction by the controlling entity. A holding company structure located in the home country would likely not be sufficient to establish control.

See J. Pohl, K. Mashigo and A. Nohen (2012), Dispute Settlement Provisions in International Investment Agreements: A Large Sample Survey, OECD Working Paper on International Investment, 2012/02, p. 20.

While the focus here is on ISDS, access to justice for the company in the domestic courts also raises issues. (See below section C.4 on Treaty requirements to use domestic courts and SRL).

As noted, the general availability of SRL in ISDS eliminates the issue of company neutralisation for foreign covered shareholders although not for other stakeholders. However, it has broader policy 
Domestic law in some jurisdictions recognises an exception to the general no reflective loss rule where the defendant has rendered the company unable to defend its rights ${ }^{46}$ Courts in other jurisdictions, however, have expressly rejected the proposed exception to the bar on SRL. ${ }^{47}$ They have found that to address the problem of company neutralisation by the defendant, the courts should allow a shareholder to bring a derivative action (for company recovery) rather than grant exceptional access to individual recovery of reflective loss. This approach avoids injury to creditors and the other shareholders.

Derivative claims mechanisms can solve the problem of neutralisation of the company because the foreign controlling shareholder's ability to bring the case on behalf of the company is usually not affected by misconduct towards the company. Recovery would be for the company so that creditors and the other shareholders would also benefit. However, treaties with deemed company mechanisms do not usually also provide for derivative actions.

\section{iii. $\quad$ Coverage of claims in non-ICSID arbitral fora}

The main issue here is whether the deeming provision applies generally to company claims under the investment treaty in all arbitral fora made available under the investment treaty (rather than only to ICSID claims). ${ }^{48}$ Treaty language in deeming clauses varies. The deeming clause in the draft Multilateral Agreement on Investment (MAI) expressly applied both for the MAI treaty generally and to provide consent for ICSID. ${ }^{49}$ It thus covered all dispute settlement options. Other treaties include a deeming provision that applies "in accordance with" ICSID art. 25(2)(b). ${ }^{50}$ Some treaties include a deeming provision that states that it applies "for purposes of ICSID" and for purposes of the ICSID Additional Facility Rules. ${ }^{51}$

\section{Issues for discussion}

- Company recovery regimes are included in a substantial number of treaties. Do you agree that SRL, where available, is likely to lead to the disuse of company recovery regimes for investment treaty claims? If so, what are the consequences of this trend in your view? Is it likely to have an impact on consistency?

consequences, as outlined generally in Investment Treaties as Corporate Law. It will also likely make company recovery in ISDS a rarity.

See, e.g., Giles v. Rhind, [2002] EWCA Civ 1428 (England). See, e.g., Waddington Ltd. v. Chan Chun Hoo, [2009] 4 HKC 381 (Hong Kong Ct. of Final Appeal 2008).

Non-ICSID fora are primarily designed for commercial arbitration claims. Unlike ICSID, they do not contain any general requirement that the claimant be of a different nationality than the respondent. The issue is thus limited to ensuring that investment treaty requirements are satisfied.

See Multilateral Agreement on Investment, Draft Consolidated Text (22 April 1998), p. 71 [DAFFE/MAI(98)7/REV1] ("the [deemed company] shall, for purposes of disputes concerning that investment, be considered 'an investor of another Contracting Party' under this article and 'a national of another Contracting State' for purposes of Article 25(2)(b) of the ICSID Convention ...").

See, e.g., Argentina-US art VII(8) ("For purposes of an arbitration held under paragraph 3 of this Article, any company legally constituted under the applicable laws and regulations of a Party or a political subdivision thereof but that, immediately before the occurrence of the event or events giving rise to the dispute, was an investment of nationals or companies of the other Party, shall be treated as a national or company of such other Party in accordance with Article 25(2)(b) of the ICSID Convention.”)

See, e.g., ECT, art.26(7). 
- The availability of company recovery is a core reason for the bar on SRL in domestic law. In your view, why has it not affected the availability of SRL in ISDS?

- Do your country's treaties include provisions allowing for deemed company claims? Have you had experience responding to deemed company claims under investment treaties? Have controlling investors from your country been associated with claims by deemed foreign companies against other governments?

- Is neutralisation of the company a serious risk for deemed company regimes in your view?

- From a policy perspective, what are the advantages and disadvantages of SRL versus company recovery?

\section{b. Derivative claims on behalf of the company}

\section{i. Introduction}

Derivative action mechanisms are widely available in advanced national systems of corporate law. In some cases, they have been introduced recently by statute. Shareholders regularly bring derivative actions in a few jurisdictions (including the United States and Japan); in others, derivative actions are rarely used. As noted in Investment Treaties as Corporate Law, domestic derivative actions serve to protect minority shareholders (and other stakeholders) from certain failures of corporate governance. Under certain conditions, minority non-controlling shareholders are permitted to bring claims on behalf of the company and with recovery for the company. The general bar on SRL in domestic law means that derivative actions are often the only way that an individual shareholder can react to reflective loss.

A small but growing number of investment treaties provide for derivative actions, generally following the model introduced by NAFTA. For example, several recent Chilean treaties incorporate derivative actions. $^{52}$ The 2004 Japan-Mexico EPA also provides for a derivative action. ${ }^{53}$ The US and Canadian model BITs similarly contain derivative action mechanisms. ${ }^{54}$

Derivative actions in investment treaties are not designed to address corporate governance issues. Rather, they seek to allow a controlling shareholder to obtain recovery in ISDS for a domesticallyincorporated company that would otherwise be barred from recovering in ISDS due to its nationality. It has been described as a mechanism to overcome the limitation of shareholder rights in customary international law to the recovery of direct injury, without allowing for SRL:

If the host State were to injure that enterprise in a manner that does not directly injure the investor/shareholders, no remedy would ordinarily be available under customary international law. In such a case, the loss or damage is suffered by the corporation. As the investor has not suffered direct loss or damage, it does not have standing to bring a claim. Nor may

$52 \quad$ See, e.g., Chile-Japan art. 89(b); Chile-Mexico art. 9-18.

53 Japanese treaty practice reveals a variety of approaches. Japanese treaties have usually provided for a deeming mechanism referring to ICSID article 25(2)(b). More recent Japanese treaties, however, have omitted this clause and, as noted here, some have included derivative action mechanisms. See Shotaro Hamamoto \& Luke Nottage, Japan, in Chester Brown, ed., Commentaries on Selected Model investment Treaties (2013), p. 356 et seq. 
the corporation itself maintain an international claim against the State of which it is a national. [The derivative action] addresses this problem by creating a right to present a claim not found in customary international law. Where the investment is an enterprise of another Party, an investor of a Party that owns or controls the enterprise may submit a claim on behalf of the enterprise for loss or damage incurred by the enterprise. ${ }^{55}$

The basic structure is generally the same. The treaty explicitly distinguishes between (i) claim brought by investors on their own behalf (an "individual claim"); and (ii) claims brought by an investor on behalf of a domestic enterprise that it owns or controls (a "derivative claim"). The derivative action applies where "the enterprise has incurred loss or damage by reason of, or arising out of, the breach." As described further below, both the controlling shareholder and the company must waive access to alternative fora at the outset of a derivative claim. (See below section C.1.b on Claim-limiting provisions)

In derivative claims, tribunals must make awards payable to the company rather than the shareholder. As in domestic law, recovery for the company is mandated in order to protect creditors, non-claimant shareholders and other stakeholders. Protection of priority creditor claims on company assets is also further addressed in some cases by provisions that the ISDS award does not affect creditor rights under national law. ${ }^{56}$ This provision "reinforces the goal of preventing shareholders from stripping away a corporate asset to the detriment of creditors". 57

As with the deeming mechanism, actual use in practice of the derivative action mechanism will likely depend on whether it is generally interpreted, as under domestic law, as the only method for a shareholder to claim for injury to the domestic company in ISDS. Shareholders will likely prefer SRL over the derivative action if SRL are available alongside the derivative action.

Derivative actions are representative actions: the named claimant is expressly acting "on behalf" of a broader group or a broader interest.

\section{ii. $\quad$ The derivative action as a representative action: the controlling shareholder as agent}

Control of the ISDS case by a controlling shareholder rather than the company has several consequences. First, concerns about the nationality of the operating company interfering with its access to recovery in ISDS are eliminated. The foreign shareholder has the requisite nationality and the company nationality is not a bar to the claim on its behalf.

Second, as noted above, the risks associated with host-state neutralisation of the company may be significantly reduced. The foreign shareholder, typically located outside the host state jurisdiction and subject to foreign company law, is likely to be able to bring the derivative claim regardless of host government efforts to block its claim or to interfere with the operating company. The host government has limited ability to interfere with the foreign shareholder's bringing of the claim. Attempts to interfere with

GAMI v. Mexico, Submission of the United States (non-disputing party) (30 June 2003) $\S \S 11-12,14$ (footnotes omitted); id, Escrito de Contestación of Mexico, p. 63 n.158 (24 Nov. 2003) (quoting and agreeing with US submission).

A number of derivative action mechanisms in treaties require that the award provide that it is made without prejudice to any right that any person may have in the relief under applicable domestic law. See, e.g., NAFTA, art. 1135(2)(c); China-Mexico, art. 20(2)(c).

Lee Caplan et al, Commentary on the US 2012 Model BIT, in Chester Brown, ed., Commentaries on Selected Model Investment Treaties (2013), p. 826 (referring to art. 34(2) of the US 2012 BIT). 
the operating company will likely simply add to the derivative claims at issue in the case. This may be a significant difference with the deemed company regime.

Third, while the representative nature of the derivative action may offer some advantages, it also can raise some issues. Representative actions can create agency problems because the interests of the agent (the named controlling shareholder claimant) are generally not fully aligned with the interests of the principal (the company and thus all company stakeholders). This can be illustrated in the context of settlement incentives.

Domestic derivative statutes provide for a number of safeguards to protect against shareholder opportunism in the settlement context. They focus in particular on the required disclosure of all settlement terms (including side payments) and/or court approval of the settlement. For example, the 2005 German statute requires publicity of the claim and its termination. Termination of the claim is not affected by a lack of publicity. However, all settlement payments must be disclosed under pain of nullity; any settlement payments made are recoverable if they were not disclosed. The representative shareholder who settles collusively thus risks finding that its release of the claim is valid, but that it has no right to collect the settlement amounts and must refund any moneys received. The statute expressly applies to pre-claim as well as post-claim settlements. ${ }^{58}$

The typical treaty requirement that the representative shareholder have ownership or control means that it has a substantial stake in the company; this helps to align its interests with company interests. Nonetheless, some agency issues may exist. The nature and intensity of the concerns in ISDS may depend in part on whether SRL are available alongside the derivative action. If the derivative action is the exclusive method for recovery of company loss under ISDS and SRL are excluded, the risk of controlling shareholder opportunism would be limited. The only claim that could be brought for injury to the company would be the derivative claim. The requirement that awards provide for recovery for the company helps to align the interests: the controlling shareholder maximises its recovery by maximising company recovery. It appears that most treaty provisions on company recovery in derivative claims are limited to actual payment of the award; they do not address settlement. Nonetheless, if the controlling shareholder individually took a side payment to terminate the derivative claim, it would likely be seen as taking for itself a company asset to which it has no right.

If SRL are available, however, both the shareholder and the company have rights (in ISDS) to the same asset (the company claim). It may be less clear that the shareholder is taking a corporate asset. The controlling (and representative) shareholder could be subject to significant conflicts of interest particularly if, as often happens, it files both an individual and a derivative claim for the same damages.

Minority shareholders and other stakeholders who rely on company recovery are especially vulnerable because the company typically must file a waiver of alternative fora, including the domestic courts, at the outset of the derivative claim. Their sole avenue of redress is in the hands of the (possibly conflicted) controlling shareholder who has complete control over the case.

A derivative action regime interpreted as merely an option alongside SRL thus appears to create significant risks that the controlling shareholder will be subject to conflicts of interest. The new risks created by allowing both types of claims could conceivably be addressed under some corporate law systems by subjecting the controlling shareholder to a fiduciary duty to the other shareholders or to the company. Even assuming this were done, however, views may differ on whether it would effectively 
address the risks created by allowing both claims. As noted in the FOI Roundtable discussion, enforcement of corporate governance norms may be weak in many host states.

The company claim regime may in some cases provide better protection to the company than the derivative action in this area because the company itself controls the claim rather than the controlling shareholder. The company also controls settlement of its claim. The board of the company may be better placed than the controlling shareholder to make decisions in the interests of the company as a whole.

\section{Issues for discussion}

- Do your government's treaties include company recovery mechanisms? Does your government have a preferred approach? On what basis?

- How do the company claims and derivative action models for company recovery compare in your view?

\section{c. Express clarification of treatment of minority shareholders and reflective loss}

The 2008 China-Mexico treaty appears to address company recovery in somewhat different conceptual terms. It is also unusual in containing a clause that expressly clarifies the parties' understanding that reflective loss claims by minority shareholders are excluded. Minority shareholders can bring claims for direct loss, but not for reflective loss.

The treaty does not provide for shareholder claims "on behalf of" a company as in the case of derivative actions. Nor does it provide rights for domestically-incorporated companies. Instead, the treaty appears to contemplate claims by controlling shareholders "for loss to an enterprise". The treaty expressly provides for company recovery if the claim is for loss to an enterprise. ${ }^{59}$ The treaty thus applies the same company recovery principle as under the derivative action. The differences in practice appear to be slight. ${ }^{60}$

In art. 13(8), the Contracting Parties recognize limits on claims by minority non-controlling investors and that claims for reflective loss by such claimants are excluded. Minority shareholders have standing only to claim for "direct loss or damage to their own legal interest as investors". The clause appears to clarify that normal corporate law principles barring SRL apply to minority shareholders under the treaty.

\section{Beyond domestic companies: coverage of the complete corporate chain of shareholders}

Most treaty regimes for company recovery based on foreign shareholder control provide for recovery by foreign-controlled domestic companies, i.e., companies incorporated in the host state.

See China-Mexico, art. 20(2) ("Where a claim is submitted to arbitration for loss or damages to an enterprise: (a) an award of restitution in kind shall provide that restitution be made to the enterprise; (b) an award of monetary damages and any applicable interest shall provide that the sum be paid to the enterprise... )

Contrary to derivative action mechanisms in other treaties, the China-Mexico treaty does not expressly provide that only controlling shareholders can claim for loss to a controlled enterprise. However, it appears to achieve the same result by clarifying that minority shareholders cannot claim for loss to the company (see below). 
Some treaties, however, such as the Netherlands 2004 Model BIT, are broader. Under the Dutch Model BIT, coverage extends through all the controlled companies in the corporate chain between the highest-level Dutch controlling entity ${ }^{61}$ and the injured company.

The intermediate controlled companies between the highest-level Dutch controlling company and the directly-injured company are indirect shareholders of the injured company. To the extent that indirect shareholders are covered, they are able to claim as shareholders with deemed Dutch nationality under the Netherlands model treaty. The injured domestic company can also claim as a Dutch foreign-controlled company as noted above. ${ }^{62}$

The claim (and thus the recovery) can likely be shifted to an entity in any jurisdiction regardless of where the controlled entity is incorporated or does business. From a corporate law perspective, this maximises shareholder power to shift the asset within a corporate chain. This could potentially include transfers of the claim to the detriment of creditors, other shareholders or tax authorities. ${ }^{63}$

Like most BITs, the Netherlands Model treaty does not expressly address the type of loss recoverable by shareholders, but arbitrators have regularly found that SRL are permitted including by third country companies.

\section{Issues for discussion}

- Have investors used the third country shareholder potential of these treaties in many cases? What are the pros and cons of this approach?

\section{5. "Foreign control" and other criteria for application of the company recovery regimes}

As noted above, if SRL are available, company recovery may have little practical policy importance because shareholders will generally prefer SRL. The same is naturally true of the criteria for access to company recovery. Attention to the criteria for company recovery is thus primarily of relevance for governments that exclude or limit SRL.

\section{a. $\quad$ Treaty practice}

Treaty practice on the criteria for access to company recovery varies considerably. Criteria used include, among others, effective control; majority share ownership; ownership or control; and control.

A first group of treaties requires control in fact or effective control. Article 26(7) of the ECT requires that the local entity be "controlled" by investors of another Contracting Party. Control for purposes of art.

61 The highest level Dutch company is not necessarily the top tier company. To the extent control is interpreted as including legal control as opposed to effective control, it may be an intermediate-level holding company controlled by another company.

In contrast, coverage of multiple entities in a corporate chain using other treaties typically requires multiple treaties. A separate treaty with the host country may need to exist with the various states of incorporation of each covered entity.

See David Gaukrodger, Investment treaties and shareholder claims for reflective loss: Insights from advanced systems of corporate law, OECD Working Paper on Investment 2014/02, Box 1, p. 20 (discussing risks to creditors and tax authorities from assets being moved around corporate chains). 
26(7) is not defined, but an understanding with regard to another provision referring to control, which refers to control in fact, may be relevant. ${ }^{64}$

Other treaties use different defined criteria. For example, a number of UK treaties require majority share ownership. The Chile-Japan treaty expressly defines ownership and control in relatively narrow terms. Ownership requires beneficial ownership of more than $50 \%$ of the company. Control requires the power to name a majority of the directors or the power to legally direct its operations under domestic law. ${ }^{65}$ This clarifies the conditions for the availability of the derivative action.

A third approach, used in NAFTA treaties, refers to ownership or control, but without defining those terms. Article 1117(1) of NAFTA requires that the derivative claimant own or control the enterprise directly or indirectly. ${ }^{66}$ Whether the purported owning or controlling shareholder can supply the necessary company waiver for a derivative action is a practical test of the shareholder's degree of control over the company.

Other treaties refer to control by nationals of the other Contracting Party in accordance with or for purposes of article 25(2)(b) of ICSID. ${ }^{67}$

\section{b. The ICSID criteria}

The ICSID Convention requirement of "foreign control" applies both to contract and treaty claims. ${ }^{68}$ The context and policy issues raised by contracts and treaties would appear to differ significantly. Contracts involve individualised agreements to ICSID arbitration. In the treaty context, the criteria for access to company recovery help determine which types of foreign investment will benefit from treaty protections.

64 The notion of "control" is used as part of the definition of investment in ECT art. 1(6). Understandings adopted as part of the Final Act of the European Energy Charter Conference provide guidance as to the meaning of "control" in the context of art. 1(6), but there is no Understanding with regard to art. 26(7). The Understanding makes clear that control in fact is required and that all relevant factors should be considered. It also places the burden of proof on the investor:

"With regard to Article 1(6): For greater clarity as to whether an Investment made in the Area of one Contracting Party is controlled, directly or indirectly, by an Investor of any other Contracting Party, control of an Investment means control in fact, determined after an examination of the actual circumstances in each situation. In any such examination, all relevant factors should be considered, including the Investor's (a) financial interest, including equity interest, in the Investment; (b) ability to exercise substantial influence over the management and operation of the Investment; and (c) ability to exercise substantial influence over the selection of members of the board of directors or any other managing body. Where there is doubt as to whether an Investor controls, directly or indirectly, an Investment, an Investor claiming such control has the burden of proof that such control exists." See Understandings to the Energy Charter Treaty adopted by signing the Final Act of the European Energy Charter Conference.

Chile-Japan, art. 105(2).

See also Canada-Peru, art. 23(1); US 2012 Model BIT, art. 24(1)(b).

See, e.g., Argentina-US, art. VII(8); ECT art.26(7).

Article 25(2)(b) provides in relevant part as follows:

"National of Another Contracting State" means: [...] any juridical person which had the nationality of the Contracting State party to the dispute on that date and which, because of foreign control, the parties have agreed should be treated as a national of another Contracting State for the purposes of this Convention. 
As in the case of the availability of company recovery, governments may want to ensure that the criteria for access to company recovery under their investment treaties apply in the same manner regardless of an investor's choice of ICSID or another arbitral forum. They may also want to determine whether to establish an autonomous criterion or use language that suggests use of or alignment with the ICSID criterion.

\section{Issues for discussion}

- What are the costs and benefits of defining control versus leaving the concept undefined?

- What are the practical consequences of the differing standards for access to company recovery, such as effective control versus legal control?

\section{Consequences for investor protection of shareholder claim regimes and company recovery regimes in investment treaties}

As suggested in the March 2013 FOI Roundtable discussion, it is important to consider the possible effects of the regimes described above on the protection of investors and investor incentives. From the analysis above, it is possible to identify three broad types of regimes for analytical purposes. The first is a company recovery regime: the foreign-controlled company is given access to recovery in ISDS, but SRL are excluded. This corresponds for example to the US 2012 Model BIT. The second is a broad SRL regime in which all foreign covered shareholders can claim for reflective loss. This corresponds to the traditional BIT as interpreted by a number of arbitral tribunals and to views of a number of commentators. A third conceivable regime generally excludes SRL in a manner similar to domestic law and general international law. Shareholder claims would be limited to claims for direct loss such as interference with shareholder rights or expropriation. Shareholders would look to the company to seek recovery for its losses. ${ }^{69}$

\section{a. Investor protection under a company recovery regime without shareholder claims for reflective loss \\ i. $\quad$ All investors and participants in covered foreign-controlled companies are protected}

A company recovery regime distinguishes between stakeholders in covered foreign controlled companies and stakeholders in other companies. Broad protection for the full range of injury to the company is driven by the foreign control. Foreign controlling investors are (indirectly) protected through their ability to claim on behalf of (or recover through) the company. Other investors (local and foreign) who join with the foreign controlling shareholder in investing in the company are also (indirectly) protected by the company recovery. Other equity and debt investors, key personnel, suppliers and others are thus given an incentive to work with covered foreign controlling investors because the controlled company as a whole is protected.

Investors and participants in a company with the covered foreign controlling shareholder are largely dependent on the decision of that shareholder about whether to claim. The dependency is arguably greater in the context of the derivative action - where the controlling shareholder has sole control of the case exceptions to the general rules is omitted at this stage. Most national systems recognise some exceptions to the general bar on SRL and similar exceptions could be considered under that regime in ISDS. See Investment Treaties as Corporate Law, pp. 20-21. Depending on their scope, exceptions could significantly affect the conclusions about investor protection under each regime outlined here. 
than under company claim regimes - where decisions are taken by the company board. The exclusion of SRL, however, largely aligns the interests of the controlling shareholder with those of the other interests in the company.

The indirect protection of non-covered investors in covered foreign-controlled companies is consistent with corporate law principles that generally apply to derivative actions, such as the equal treatment of shareholders and the protection of creditors through company recovery. These corporate law principles are designed to protect creditors and minority shareholders (and thus encourage them to invest).

The indirect protection of non-covered investors in covered foreign-controlled companies to ISDS standards, however, can be expensive for respondent governments. As noted in earlier FOI Roundtable discussions, ISDS is an exceptional regime that provides money damage remedies that are generally unavailable to domestic investors; the latter are generally restricted to primary (non-pecuniary) remedies. ${ }^{70}$ It is cheaper for a government to provide the exceptional damages remedy to a $30 \%$ or $50 \%$ or even an $80 \%$ foreign shareholder than to the entire company.

\section{ii. Likelihood of pressure on the exclusion of shareholder claims for reflective loss in a case law} context

In the context of litigation, there may be strong pressure on the respondent government and its counsel to minimise the amount of damages through whatever means are available. To reduce their damages in a particular case, some respondent governments may be inclined to support a shareholder reflective loss recovery rather than a company remedy.

This may put significant pressure on the treaty exclusion of SRL especially in derivative action regimes. All parties in the case may have economic incentives to favour a shareholder reflective loss recovery rather than company recovery. Shareholders generally prefer SRL if they are available, as noted above. The government may seek primarily to limit its damages liability. Those who may suffer from SRL -- creditors and non-claiming shareholders -- are not represented. The arbitral tribunal may hesitate to uphold the logic of company recovery if both disputing parties are favouring recovery of reflective loss by a shareholder.

Respondent governments may thus favour SRL in the context of a particular claim because of its lower immediate financial (and political) cost. However, corporate law analysis suggests it may have potential systemic costs and impact on overall investment. Ideally, the issues should be analysed with expert input and a clear decision made. Non-disputing government parties to the treaty may also want to monitor cases to ensure that broader interests are reflected as appropriate.

\section{iii. $\quad$ Foreign covered shareholders of non-covered companies are covered only for direct injury}

Foreign covered shareholders of non-covered companies (including domestic companies) receive more limited protection. They are protected in the exercise of their direct shareholder rights including from expropriation of company assets. They are not protected, however, for reflective loss in ISDS; they must rely on the company's recourse.

Access to money damages for investors under advanced national systems of administrative law is in practice limited to expropriation or contract claims. See FOI Roundtable Progress Report on ISDS, p. 10; ISDS Scoping Paper, pp. 25-27 \& Annex 4. 


\section{$i v . \quad$ Impact of the criteria for access to company recovery}

The criteria for access to company recovery will help determine the categories of foreign (and domestic) share ownership that will qualify for risk protection beyond protection for direct rights. If the threshold for access to company recovery is relatively high, such as effective control or ownership of more than $50 \%$ of the shares, protection of investors from non-expropriation risks would be limited to those participating in companies with clear (effective or legal) control by a foreign covered shareholder. If the threshold for access to company recovery is lower, protection from non-expropriation risks may extend to stakeholders in companies with less foreign ownership. A broader criterion could reach out to cover companies with a $20 \%$ shareholder (or less) under certain conditions.

Second, the criteria for company recovery may also determine the extent to which creditors and nonclaimant shareholders (including domestic shareholders) will be (passively) "carried along" with the covered foreign shareholder. For example, if 30\% ownership can satisfy the criterion under some conditions, a 30\% covered shareholder could initiate a company claim for recovery of $100 \%$ of its damages. In this case, $70 \%$ or more of the recovery could go (indirectly) to non-covered stakeholders (including creditors and the other shareholders). In contrast, if foreign control requires $50 \%$ ownership, the amount of damages that benefit non-covered stakeholders would be closer to $50 \%$.

The criteria can also help define types of foreign input (other than share ownership) that will attract protection. For example, requiring effective control or control in fact may help promote transfers of management expertise. However, requiring inputs from a particular country may interfere with efficient management or introduce uncertainty about treaty coverage.

A company recovery regime without SRL thus appears to be focused on promoting foreign direct investment. Foreign investors in domestic companies have a clear incentive to have control because they are otherwise limited to coverage for direct loss. Other investors have an incentive to invest in foreigncontrolled ventures because those who invest alongside the controlling shareholder in the company are also protected. Covered FDI is promoted both in itself and because those who associate with it, whether individually covered or not, can benefit from the full range of treaty protection for the company. Covered minority foreign shareholders of other companies benefit from a narrower range of protection, limited to their direct shareholder rights.

\section{Issues for discussion}

- ISDS provides damages remedies that are not generally available to companies in national systems of administrative law (except for expropriation). Providing these exceptional damages remedies to the whole company costs more than would be the case if the government's exposure is limited to only certain shareholder claims for their share of government injury to the company. In contrast, advanced national corporate law generally bars SRL and allows only company recovery in part because it protects investors such as creditors and the other shareholders, and thus encourages them to invest in companies. How can these policy goals of corporate law best be integrated with ISDS?

- Should the issues be addressed at the treaty drafting stage and express language used to achieve the desired result as between company recovery or SRL? How would this approach in new treaties affect existing treaties (without express language) where governments consider that SRL are excluded, but arbitral case law is uncertain? Are clarifications and jointly agreed understandings of existing language useful in this context?

- Could greater recourse to primary remedies in ISDS or other changes to ISDS help integrate the policy goals? 


\section{b. Investor protection under treaties that permit shareholder claims for reflective loss by covered shareholders}

In contrast to the company recovery regime, which focuses on foreign control, the SRL regime focuses on foreignness. The regime distinguishes between foreign and domestic shareholders. Foreign control has limited significance.

Foreign covered shareholders are covered for the full range of company injury regardless of whether they have a controlling stake. Domestic and other non-covered investors are excluded from indirect protection through the company. Participation in a foreign-controlled investment does not provide noncovered investors any indirect protection.

As outlined in Investment Treaties as Corporate Law, the result of this regime is likely to divide shareholders into three broad categories: (1) Category I - "Likely claimants" - covered shareholders who have a sufficient stake to make bringing a claim worthwhile; (2) Category II - "Potential but unlikely claimants" - covered shareholders who are unlikely to bring SRL due to the limited size of their investment or their diversified investment strategy and whose fortunes lie principally with company remedies; and (3) Category III - "Excluded claimants" - foreign non-covered shareholders and domestic shareholders, who cannot bring a claim as a shareholder under either ISDS or domestic law, and whose fortunes lie solely with company remedies. ${ }^{71}$

Since treaty coverage gives Category I shareholders access to exceptional ISDS damages remedies and SRL, interest among significant investors in making investments with treaty coverage as shareholders should be strong.

Smaller covered interests, however, may be largely excluded from protection. The practical exclusion of company remedies in favour of SRL means that smaller or diversified interests, whose fortunes lie primarily or exclusively with company remedies, may be less frequently protected.

This regime would thus appear to protect and promote foreign investment in particular by large minority shareholders. It may provide less support for FDI than a company recovery regime. Only the controlling shareholder (or other major foreign covered shareholder) is protected rather than all participants in FDI. It provides considerably more protection to Category I minority shareholders. Large non-covered investors may have a strong incentive to seek to structure their share investments to obtain protection as foreign shareholders to the extent possible. Category II and III shareholders are less protected, which may affect their incentive to invest. ${ }^{72}$

\section{c. Investor protection analogous to traditional corporate law rules without a company recovery regime in ISDS}

The third approach restricts the range of covered shareholder interests. It also does not provide for a company recovery regime in ISDS. All covered foreign shareholders are covered in ISDS for infringement

71 See Investment Treaties as Corporate Law, pp. 47-48.

72 Due to its recent development and complexity, the ISDS system may not be well understood at present especially by some potential and actual Category II and III investors. The differential treatment of shareholders may only become apparent to those investors after some high-profile cases (involving both ISDS and domestic proceedings) generate outcomes that differ significantly for covered and non-covered shareholders of the same company. 
of their direct rights including expropriation, but are otherwise dependent on the company's ability to obtain a remedy under domestic law or under a contractually-agreed arbitration clause.

This approach encourages investments by a covered foreign company itself rather than through establishing a domestic company or acquiring shares in domestic companies. Foreign investors would likely be discouraged from setting up local subsidiaries. This would significantly reduce the incentive for investments through shares or investments that require a domestic subsidiary for effective operation.

\section{Issues for discussion}

- The paper suggests that the various shareholder claim and company recovery regimes may have significantly different effects in terms of the type of investment that they protect and promote. What are your views? Has your government considered the effects of the shareholder claim and company recovery regimes in its treaties on the types of investment that it is seeking to encourage and the expected costs of providing protection? 


\section{INTERACTION OF SHAREHOLDER CLAIM AND COMPANY RECOVERY REGIMES WITH SELECTED TREATY PROVISIONS}

This section preliminarily analyses how shareholder and company recovery regimes interact with selected treaty provisions. As noted above, SRL can give rise to two types of multiple claims arising out of the same injury to a company: (i) "overlapping" claims - claims by shareholders and/or the company who have common ownership; and (ii) "related" claims - claims by unrelated shareholders of the same company.

This section first looks at claim-limiting provisions (waiver requirements, so-called "no u-turn" regimes or fork in the road clauses) which seek to exclude certain overlapping claims. The analysis then turns to consolidation provisions, which regulate the possible joinder of overlapping or related claims in a single consolidated proceeding; denial of benefits clauses, which allow the government to limit the types of companies that can bring claims; requirements to use domestic courts; time limits on the bringing of claims; and provisions for binding party interpretation of treaties.

\section{Claim-limiting provisions: Waiver, no u-turn, fork in the road, etc.}

Reflective loss is incurred by shareholders as a result of direct loss by the company. If SRL are available, one or more shareholders and the company can bring overlapping claims arising out of the same injury. Overlapping claims will frequently be possible if (i) SRL are permitted; and (ii) indirect shareholders are covered. The overlapping claims may include the claim for direct loss by the company as well as one or more SRL.

Overlapping claims arising out of the same events and injury can be costly and wasteful; while necessary in some cases, they are generally contrary to principles of judicial economy. They can also give the same beneficial owner of shares "two bites at the apple", which is widely seen as contrary to basic principles of fairness. For these reasons, and because they can lead to inconsistent outcomes, they may also affect the legitimacy of the ISDS system. Many governments have included provisions in treaties that seek to limit overlapping claims. They take various forms.

A number of treaties require a waiver of recourse in other fora as a condition of access to ISDS. ${ }^{73}$ NAFTA and certain other treaties have adopted a specific procedure often referred as a no u-turn rule. Covered parties can commence proceedings in the domestic courts without affecting their right to ISDS (providing the three year time limit for ISDS claims does not expire). The choice of ISDS, however, is definitive: existing domestic proceedings must be discontinued and there can be no subsequent "u-turn" back to the domestic courts. Treaties can also provide for a fork in the road that requires a definitive choice of a single forum for resolution of claims relating to the government measures at issue, such as a choice between the domestic courts and ISDS.

Governments that wish to allow SRL may nonetheless want to limit the risk of multiple overlapping claims. It appears, however, that achieving this combination may involve significant treaty drafting challenges. This discussion below reviews (a) the likely limited effectiveness of claim-limiting provisions 
addressed only to the claimant entity if SRL are available; (b) regimes which limit claims by both the controlling shareholder and the company; and (c) treaty language that provides that a claim by a lower-tier company pre-empts claims by a higher-tier shareholder.

\section{a. Claim-limiting provisions addressed only to the claimant entity may have little effectiveness if shareholder claims for reflective loss are permitted}

Many claim-limiting treaty provisions are addressed only to a single entity, the claimant. ${ }^{74}$ Such provisions may be effective to limit alternative claims if SRL are generally barred. In that case, only the directly injured entity would be able to successfully claim in ISDS. Its access to alternative fora would be limited by the treaty provision.

If SRL are available, however, essentially the same claim can be raised by other entities in the chain of ownership. A claim-limiting provision addressed only to the claimant will not normally apply to its parent companies and subsidiaries. Provisions barring or limiting only the claimant entity from alternative fora may not significantly limit the potential for multiple overlapping claims.

\section{b. Claim-limiting provisions and company recovery regimes}

Treaties with company recovery regimes may also include claim-limiting provisions. For example, NAFTA's derivative claims regime limits overlapping claims by the claimant shareholder and the company. The no u-turn regime outlined above applies to both the controlling shareholder claimant and the company; both must waive their recourse to alternative fora at the time that the derivative claim is filed. ${ }^{75}$

The effectiveness of these provisions will likely depend on whether the company recovery regime is the exclusive method of recovery for injury to the company (i.e., whether SRL are available). If the company recovery regime is exclusive, limits on alternative claims by the company will bar other

74 See, e.g., China-Japan-Korea art. 15(6) (requiring written waiver of rights to go to host state national courts only by the "disputing investor"); id. art.15(5) (same limitation for fork in road); ACIA art. 34(1)(c) (requiring waiver only by the "disputing investor"); US-Czech, US-Slovak Republic art. VI(3)(ii) (fork in road applicable only if the [claimant] has brought the dispute before the national courts).

NAFTA also contains a fork in the road applicable only to certain claims against Mexico. In Mexico, international law norms such as NAFTA provisions may in some cases be invoked in the domestic courts. Accordingly, investors may be able to invoke NAFTA provisions both in arbitration and in Mexican proceedings. Annex 1120.1 avoids duplicative proceedings of this type. It bars duplicative domestic and ISDS treaty claims by an investor; it also bars duplicative claims by a controlling shareholder and its controlled company. See NAFTA Annex 1120.1 (providing that where a foreign NAFTA-party controlled company invokes certain NAFTA investment provisions in Mexican proceedings, the controlling shareholder cannot allege the same breach in NAFTA arbitration proceedings). See also China-Mexico Annex B (Annex to Article 13 paragraph 1) (barring duplicative domestic and ISDS claims by an investor or by an investor and an investor-controlled company).

Governments that want to provide for SRL in ISDS and whose national legal systems allow the direct application of treaties in the domestic courts may wish to consider the shareholder claims regime that will be applicable to treaty-based claims in the domestic courts. In particular, they may want to address whether SRL will be governed by rules akin to national law - which generally bar such claims - or the special ISDS regime. If covered shareholders can bring SRL in national courts while other shareholders cannot, the differential treatment will likely be more visible than in ISDS and may thus have a greater effect on capital markets and company financing. On the other hand, if the domestic court regime restricts SRL, shareholder claimants with access to SRL in ISDS would normally choose ISDS. 
overlapping claims. If SRL are possible alongside the company claim, treaty limits on alternative company claims may be circumvented by having a shareholder bring the alternative claim.

If a derivative action regime is exclusive, limits on alternative claims by the controlling shareholder and the company will bar other overlapping claims. If SRL are possible, treaty limits on controlling shareholder and company claims in alternative fora may be circumvented by having a different shareholder bring the alternative claim.

\section{c. $\quad$ Pre-emption by downstream entity claims}

As outlined in Investment Treaties as Corporate Law, the Czech Republic was subject to overlapping claims in the Lauder/CME cases. ${ }^{76}$ Czech treaties have included a provision to the effect that an ISDS claim by a downstream entity in the corporate chain under another investment treaty precludes a claim by the upstream entity. If a lower-tier shareholder claims, the higher-tier claim is barred:

If an investment is held indirectly through an investor of a third state by an investor of one Contracting Party in the territory of the other Contracting Party, the investor of a Contracting Party may not initiate or continue a proceeding under this Article if the investor of the third state submits or has submitted a claim with respect to the same measure or series of measures under any agreement between the other Contracting Party and the third state. ${ }^{77}$

This provision gives a lower-tier entity the power to pre-empt an on-going higher tier claim. This could raise shareholder conflicts or difficulties in some cases where the ownership of the two entities is only partially the same. A lower-tier entity might wait to see the initial outcomes of the higher-tier shareholder claim and then file if the outcomes are positive on key issues; the higher-tier entity would then see its case dismissed late in the proceeding.

\section{d. Conclusion}

Overall, for most shareholder structures and treaty configurations, the decision whether to file overlapping ISDS and/or domestic claims may primarily be a matter of shareholder choice. To date, it appears that overlapping ISDS claims are rare although there are some recent examples. ${ }^{78}$

Overlapping claims can provide substantial leverage to a beneficial shareholder. For example, it may get "two bites at the apple" or the ability to negotiate over consolidation from a position of strength. There may be various explanations for the rarity of overlapping ISDS claims to date notwithstanding these benefits for claimants. Shareholders and their counsel may consider that although overlapping ISDS claims are available as a matter of law, they are not advisable either as a matter of commercial relations with major creditors or as a matter of appearing reasonable to arbitrators and others. Shareholders may be satisfied with locating their claims at the optimal tier for tax, creditor and treaty considerations. In addition,

\footnotetext{
76 See Investment Treaties as Corporate Law, pp. 41-44, 49-51.

77 Canada-Czech Republic, art. X(5)(b).

For example, Egypt reportedly faces overlapping ISDS claims from shareholders and related parties with regard to alleged mistreatment of East Mediterranean Gas Company (EMG). See Luke Eric Peterson, Battle is joined on second treaty-arbitration front in Israel-Egypt gas fight, as ad-hoc arbitral tribunal is chosen, Investment Arbitration Reporter (6 Feb. 2013).
} 
in light of the widespread negative reaction to the Lauder/CME cases and their perceived impact on the legitimacy of ISDS, shareholders and their counsel may consider that arbitrators will not look favourably on overlapping claims. Arbitrators may for example interpret the definition of investment in a manner that has the effect of excluding jurisdiction over what could be perceived as an overlapping ISDS claim. ${ }^{79}$ The rarity of overlapping claims may also reflect the perceived recent nature of the ISDS rules on SRL, especially as applied to minority shareholders, which are frequently seen as dating from the 2003 decision in $C M S{ }^{80}$

Overlapping domestic and ISDS claims are already relatively frequent. Governments wishing to allow for SRL may want to consider whether the overlapping claim in ISDS for SRL should always be available notwithstanding the availability of effective company recourse in the domestic courts. Some governments may wish to consider whether SRL should be conditioned on, or limited to inquiry about, the establishment of some defect in the quality of the company's domestic recourse relating to the government measure in question.

It may be difficult to establish effective legal limits on overlapping claims if SRL are available. Both the definition of related parties and related claims (extending to claims under other treaties) may be difficult to achieve, and may have negative consequences.

In addition to considering overlapping claims, it may be important for governments to provide for mechanisms for the efficient and fair consolidation of multiple related claims into a single proceeding whenever possible.

\section{Issues for discussion}

- What is your country's experience with overlapping ISDS claims?

- What legal tools do arbitrators have under current treaties to address overlapping ISDS claims?

- It appears that overlapping ISDS claims remain relatively rare. This appears to be primarily based on discretionary decisions by shareholders not to bring overlapping claims rather than legal constraints. Can continuing restraint be relied on for the future?

- What are your views on overlapping recourse by a shareholder in ISDS and the company in the domestic courts? Should shareholder recourse be unaffected by the company's recourse?

See Standard Chartered Bank v. Tanzania, Award, ICSID (2012) (interpreting the requirement that the investment at issue must be an investment "of" the claimant and declining jurisdiction over a shareholder claim). The tribunal noted that a subsidiary of the claimant had filed a contract-based claim at ICSID against the state-owned electricity company over the same loans at issue. (Id. § 46) The existence of the contract claim was pointed out by the tribunal but was not referred to as a factor in the decision, which was based on the interpretation of the definition of investment. Additional approaches to the interpretation of the definition of investment may complicate the already uncertain case law on the meaning of investment.

CMS Gas Transmission Company v. Argentina, Decision of the Tribunal on Objections to Jurisdiction, ICSID (2003). The point here relates to perceptions. The $C M S$ tribunal considered that it was applying an already existing lex specialis based on earlier arbitral cases. Nonetheless, many treatments of the issue single out $C M S$ as a key moment because it involved a minority shareholder and addressed and rejected the application of the principles of Barcelona Traction and general international law in ISDS. See, e.g., Matthew Weiniger, The Legal Standing of Shareholders in International Law (2011). 


\section{Consolidation of claims and joinder of related claims}

SRL allows multiple unrelated covered shareholders of the same company to bring separate claims arising out of a single injury to the company. For example, both CMS and Total - which were unrelated companies - separately claimed as shareholders of TGN for alleged injury to that company. ${ }^{81}$ Recent cases and news reports suggest multiple claims by unrelated shareholders may occur frequently if SRL are permitted. ${ }^{82}$ Treaty provisions that address overlapping claims by the same entity or affiliated entities normally do not affect claims by unrelated entities.

The likelihood of multiple claims arising out of a single injury may make issues relating to consolidation of related claims of particular importance. As noted in Investment Treaties as Corporate Law, it is possible to reach ad hoc agreements to consolidate related shareholder and company claims. However, ad hoc consolidation of claims may only be offered to the respondent state under unfavourable conditions, such as acceptance of the investors' preferred tribunal. ${ }^{83}$

Consolidation provisions in treaties typically provide for equal participation of claimants and the government in the composition of a single tribunal. For example, NAFTA art. 1126 provides for the creation of a tribunal to resolve issues of consolidation (the Consolidation Tribunal). Upon application by a disputing party, a Consolidation Tribunal is appointed by the Secretary-General of ICSID. Tribunal members are to be selected if possible by the Secretary-General from a roster of 45 qualified and experienced presiding arbitrators appointed by the NAFTA parties by consensus.

The Consolidation Tribunal must decide whether claims that it considers have a common question of law or fact should be consolidated and heard by it in the interests of fair and efficient resolution of the claims. ${ }^{84}$ Where a Consolidation Tribunal has taken jurisdiction over a claim or part of a claim, other tribunals created under NAFTA no longer have jurisdiction over those matters. ${ }^{85}$ The Consolidation Tribunal only has competence over claims made under NAFTA.

In general, the Consolidation Tribunal has broad discretion to decide on consolidation of NAFTA claims. However, a specific provision applies to the consolidation of direct and derivative shareholder claims. It establishes a rebuttable presumption that consolidation of such claims is appropriate where they

See Investment Treaties as Corporate Law, pp. 37-38. As noted therein, Total filed its claim after the 2003 decision permitting the shareholder claim for reflective loss in $C M S$.

See, e.g., Luke Eric Peterson, Tribunals in place for UNCITRAL and ICSID claims against Algeria by shareholders alleging billions in losses in Djezzy telecoms venture, Investment Arbitration Reporter (25 April 2013) (separate UNCITRAL and ICSID claims by different shareholders of Algerian company); Luke Eric Peterson, India BIT claims round-up: As arbitrators are chosen in two cases, IAReporter investigates other claims, including by Russian Federation and Vodaphone, Investment Arbitration Reporter (16 April 2013) (possible separate claims by different shareholders in Indian company); Luke Eric Peterson, Battle is joined on second treaty-arbitration front in Israel-Egypt gas fight, as ad-hoc arbitral tribunal is chosen, Investment Arbitration Reporter (6 Feb. 2013) (separate claims by different shareholders of Egyptian company).

The ability to start out with several cases and then offer consolidation may offer various opportunities for tactical behaviour by sophisticated investor counsel.

NAFTA, art. 1126 (2).

Id. art. 1126(8). 
arise out of the same events. The claims "should be heard together" by a Consolidation Tribunal unless it finds that the interests of a disputing party would be prejudiced thereby. ${ }^{86}$

Assuming SRL are excluded under NAFTA, multiple claims are likely to be relatively rare: multiple claims are limited to the derivative action and/or one or more shareholder claims for direct injury. The consolidation provisions will likely apply to such situations.

The Chile-Japan SEA similarly provides for formation of a Consolidation Tribunal which is given the discretion to decide whether claims with a common question of law or fact should be consolidated and heard by it in the interests of fair and efficient resolution of the claims. ${ }^{87}$ The general regime for consolidation is applied to overlapping direct and derivative claims without an explicit presumption in favour of consolidation.

Consolidation provisions, however, can likely be skirted by shareholders if SRL are available. A consolidation provision in a treaty normally only applies to claims under that treaty. A shareholder could, for example, claim separately for essentially the same injury using an entity subject to a different treaty. The various claimant shareholders under different treaties could then negotiate about possible consolidation without any legal constraints.

\section{Issues for discussion}

- Have you had experience with the use of consolidation provisions in any of your government's treaties? Has your government been faced with multiple claims that it wished to consolidate?

- Do you have experience with ad hoc consolidations in cases involving your government's treaties?

- Should governments consider developing consolidation provisions that would apply across different treaties? Could costs rules be used as an incentive in this area to allow for more consolidations using procedures that provide equal input in the selection of the tribunal?

\section{Denial of benefits provisions}

Denial of benefits provisions have been included in a significant number of recent treaties. Typically, the provisions provide that the government reserves the right to deny benefits to a company if it is owned or controlled by third state nationals and has no substantial business activities in the home state where it is organised. ${ }^{88}$

See id. art. 1117(3) ("Where an investor makes a claim under [the derivative claim mechanism in Article 1117] and the investor or a non-controlling investor in the enterprise makes a claim under Article 1116 arising out of the same events that gave rise to the claim under this Article, and two or more of the claims are submitted to arbitration under Article 1120, the claims should be heard together by a Tribunal established under Article 1126, unless the Tribunal finds that the interests of a disputing party would be prejudiced thereby").

Chile-Japan, art. 101(7).

Denial of benefits provisions in treaties seek to address situations created by rules on corporate nationality. Many investment treaties extend home state nationality to companies based solely on their incorporation in the home state. This criterion is widely used and provides for certainty about applicable law. However, it does not require any real economic connection with the state of incorporation. 
The ECT provides for example that "[e]ach Contracting Party reserves the right to deny the advantages of this Part to ... a legal entity if citizens or nationals of a third state own or control such entity and if that entity has no substantial business activities in the Area of the Contracting Party in which it is organized." 89

\section{a. Impact of denial of benefits provisions on the consistency risks created by shareholder claims for reflective loss}

Denial of benefits places some limits on the nature of the entities that can file claims. However they would appear to be likely to have at most a limited effect on the consistency issues raised by SRL. Notwithstanding denial of benefits provisions, governments whose treaties allow for SRL can still be exposed to multiple claims by different shareholders, double recovery, the expenses of allocating reflective loss amongst various constituencies and other costs of SRL. Company creditors and the other shareholders may also be unlikely to consider that a denial of benefits provision affects the risk to corporate assets created by SRL. ${ }^{90}$

\section{b. Impact of the availability of shareholder claims for reflective loss on denial of benefits provisions}

Most denial of benefits provisions appear to be structured as a discretionary government power to deny benefits to certain investors rather than as a criterion for protection in every case. This allows governments to accord protection to some investments for which it could deny benefits. However, the denial structure creates some tensions and questions in particular with regard to the time at which the power can be exercised. The text of the provision typically does not establish any limits on timing. In some cases, prior notification or consultation of the home state government is required.

Some tribunals have suggested that the provision should be read narrowly as allowing denial of benefits only at the time of establishment of the investment, but not subsequently. ${ }^{91}$ In contrast, other

Stricter regimes for corporate nationality may thus achieve similar but broader effects than denial of benefits provisions by requiring an economic connection to the home state. See, e.g., China-Germany art. 1(2) (covering in respect of the Federal Republic of Germany, companies with their seat in the territory of the Federal Republic of Germany; in respect to the People's Republic of China, companies incorporated and constituted under the laws and regulations of and with their seats in the People's Republic of China).

ECT, art. 17(1); Chile-Japan SEA, art. 87; see also NAFTA, art.1113(2) ("Subject to prior notification and consultation in accordance with Articles 1803 (Notification and Provision of Information) and 2006 (Consultations), a Party may deny the benefits of this Chapter to an investor of another Party that is an enterprise of such Party and to investments of such investors if investors of a non-Party own or control the enterprise and the enterprise has no substantial business activities in the territory of the Party under whose law it is constituted or organized.").

Moreover, the expanded treaty shopping power created by SRL may allow an investor to avoid treaties with denial of benefits provisions. Alternatively, the transaction structure can use companies that satisfy the requirements for business activities in fora where that is required. 
tribunals have permitted post-dispute denial of benefits under certain conditions. ${ }^{92}$ This allows the government to react with knowledge of the identity of the investor.

If denial of benefits provisions require pre-investment (or even pre-dispute) notice of the decision to deny to the investor, the availability of SRL will likely present a major hurdle to the effectiveness of the provision. Governments normally have no awareness of the making of most investments at various levels of the corporate chain. Government monitoring costs to allow use of the denial of benefits provision would likely be prohibitive.

The issues appear to be somewhat different if SRL are excluded. In that case, a pre-dispute notice requirement for the denial of benefits would be less constraining on the government. Action taken against a shareholder's direct rights, such as voting rights, normally requires knowledge of - and frequently may be caused by - the identity of the shareholders at issue. Expropriation of a company's assets, which causes direct injury to shareholders, may harm some unknown shareholders who then claim for harm to their direct rights. However, coverage of unknown covered shareholders from expropriation risks is less of a constraint on government policy than coverage for all risks protected under the treaty.

If post-dispute notice is sufficient, as in Pac Rim, the SRL factor has less impact. As noted above, the main impact would likely be due to the power to treaty shop that SRL creates, which could allow investors to locate the claim where no denial of benefits provision applies.

\section{Issues for discussion}

- Do you see denial of benefits provisions as being effective in controlling consistency risks posed by SRL (assuming they are available)?

- How does the treaty shopping power made available by SRL affect denial of benefits clauses?

- Arbitrators have interpreted notice requirements for denial of benefits in different ways. How do you see the availability or not of SRL interacting with the various approaches to notice requirements?

\section{Treaty requirements to use domestic courts and the availability of shareholder claims for reflective loss}

Two types of treaty provisions may require at least some recourse to domestic law by companies seeking to establish an ISDS claim. First, at least under some treaties, it is often considered that investors must make reasonable efforts to have an improper administrative decision rectified in order to successfully claim for a breach of the fair and equitable treatment standard. Second, treaties may require that an investor have recourse to or exhaust domestic remedies prior to bringing an arbitration claim.

If SRL are available in ISDS, shareholders bringing SRL may seek to take advantage of the no reflective loss rule in domestic law with regard to treaty requirements of this type. This may raise consistency issues because shareholders bringing SRL in ISDS may have better rights than the injured company in ISDS.

See Pac Rim Cayman LLC v. Republic of El Salvador, Decision on the Respondent's Jurisdictional Objections, ICSID (2012) (permitting post-dispute invocation of CAFTA-DR's denial of benefits clause; distinguishing some earlier cases, including Plama, based on the "different wording, context and effect" of the treaties). 
In the context of claims for breach of the fair and equitable treatment provision, some tribunals have held that the standard can require investor efforts to rectify administrative misconduct and that an immediate claim in ISDS without such efforts can be rejected. This gives a government a chance to correct low-level errors and prevents an investor from immediately seeking damages and lost profits from an unchallenged administrative or lower-court decision.

Shareholders bringing SRL, however, may argue that they do not have the ability to obtain domestic redress for the measure because of their lack of standing in domestic law. Under advanced systems, shareholders have no standing to claim for injury to the company. Thus, for example, in Gemplus S.A.v. Mexico, a minority shareholder pointed to its lack of remedy as a shareholder for company injury in the Mexican courts. It also sought to distance itself from the company claim, appearing to suggest that control of the company by another made the company claim irrelevant:

the majority shareholder has initiated proceedings in the name of the [company] before the Mexican courts. The [minority shareholder] Claimants are not parties to those proceedings. It is not apparent what remedies are available to them - in their capacity as shareholders in the [company] - in any proceedings before Mexican courts. ${ }^{93}$

The situation in the Mexican courts was not unusual in this respect. Minority shareholders would likely face the same barriers in the national courts of most countries. They would also largely be subject to the will of a controlling shareholder with regard to the company's action on the claim.

It appears that while a company might be required to show that it had engaged in reasonable efforts to have an improper decision rectified by administrative courts in order to establish a breach of the fair and equitable treatment standard, a shareholder might not face a similar requirement because it would not have standing to challenge the measure under domestic law.

Similar issues arise with regard to treaty requirements that an investor have recourse to or exhaust domestic remedies prior to bringing an arbitration claim. While a company's response to initial injury may be carefully scrutinised to ensure it gave the government a chance to rectify the situation or to ensure it satisfied domestic court exhaustion requirements, a shareholder may be in much more favourable position. It could argue that it has no standing under domestic law to challenge actions injuring the company and that accordingly immediate access to ISDS should be permitted.

A shareholder may thus seek to combine use of SRL in ISDS and the no reflective loss principle in domestic law. This could allow it to avoid treaty requirements for recourse to the domestic courts on the basis that no domestic recourse is available to it due to domestic law bar on SRL. A company claim for the same injury would, in contrast, have to be preceded by the necessary company recourse in the domestic courts. As noted above, law firms producing materials describing the shareholder claims regime in ISDS have underlined that it can allow the shareholder to have better rights than the company for claims arising out of company injury. ${ }^{94}$ If SRL are permitted, this type of situation may be hard to address in treaties without changes to domestic law to expand the ability of shareholders to bring claims.

\section{Issues for discussion}

\footnotetext{
93 Gemplus S.A. et al v. The United Mexican States, Award, ICSID (2010), p. VII-8 (quoting the claimant's reply). 
- The text refers to some examples where with regard to injury to the company, shareholders have better rights than the company as a result of SRL. Is this likely to affect the relative use of SRL versus company claim mechanisms?

- Do better rights in ISDS for shareholders than for the company raise issues of consistency?

\section{Time limits}

Time limits on investors' ability to bring claims can be an important constraint on multiple shareholder and company proceedings arising out of the same events. They require all potential claimants to bring all claims within a defined time period; this may both limit claims and facilitate consolidation of overlapping claims.

As described in the ISDS treaty survey, only $7 \%$ of BITs in the sample provide for time limits on investor claims. ${ }^{95}$ The trend is increasing and many multilateral agreements contain time limits. A notable exception to the existence of time limits in multilateral treaties is the ECT. Where time limits are included, they often allow claims for a three year period. ${ }^{96}$

\section{Explicit provisions for binding treaty party resolution of interpretive issues}

A small but increasing number of treaties contain explicit provisions for binding treaty party resolution of interpretive issues. It does not appear that any governments have issued an agreed interpretation with regard to shareholder claims following entry into force of a treaty. Agreements: A Large Sample Survey, OECD Working Paper on International Investment, 2012/02, p. 18.

One tribunal ruling suggests that shareholders filing individual claims may benefit from extra time to bring claims. In Pope \& Talbot v. Canada, the tribunal found that for SRL (which it found to be available under NAFTA art. 1116 over Canada and US objections), the trigger for the start of the three year period does not occur until the shareholder (rather than the company) learns of the damage to the company and the shareholder's reflective loss. See Meg N. Kinnear et al, Investment Disputes under NAFTA, An Annotated Guide to NAFTA Chapter 11 (2006 \& 2008 Supp.), p. 1116-36 (citing Pope \& Talbot, Inc. v. Canada, Award in Relation to Preliminary Motion by Government of Canada to Strike Paragraphs 34 and 103 of the Statement of Claim from the Record, (24 Feb. 2000), § 12.) 


\section{REGIMES FOR OBJECTIONS TO SHAREHOLDER CLAIMS}

This section addresses treaty provisions relating to the resolution of objections to shareholder claims as a preliminary matter and relating to review of decisions on shareholder claims in awards.

\section{Preliminary objections to shareholder claims}

Treaty provisions allowing for the mandatory early resolution of certain issues may affect the procedures for resolving SRL and objections to them. The issues in this section are likely of interest primarily to those governments that have excluded or may be interested in excluding or limiting SRL.

The consistency costs related to SRL may be significantly reduced if SRL, where it has been decided to exclude them, can be rejected early in the case. This avoids the need to litigate all the issues raised by the claim to the conclusion of the case before it is dismissed. It may also reduce the likelihood of multiple shareholder claims arising out of the same injury.

The discussion below considers comparative law, ISDS practice and treaty provisions relating to the treatment of preliminary objections to shareholder claims.

\section{a. $\quad$ Early dismissal of shareholder claims for reflective loss is frequently available under advanced systems of national law}

In advanced systems of domestic law, the general bar on SRL is usually well-established. Shareholder claims typically do not seek to challenge the general principle excluding SRL. Rather, shareholders either (i) seek to fall within or establish an exception to the general bar on SRL; and/or (ii) argue that their claim is for direct loss.

Shareholder claims for reflective loss are often dismissed as a matter of law at the outset of the case without the parties or the court needing to incur the expense of investigating the merits. ${ }^{97}$ The issue is

In the UK, the issue is typically decided on a motion to strike the pleadings at the outset of the case based on a finding that the statement of case discloses no reasonable grounds for the claim. See Civil Procedure Rules 3.4(2)(a); Johnson v Gore Wood, [2002] 2 A.C. 1 (House of Lords); Mellor v Partridge, [2012] EWHC 1415 (QB 2012). The issue is frequently framed as one of the shareholder not being the "proper plaintiff" because the proper claimant is the company, as in Johnson, or as an application of the no reflective loss rule or principle. See Gardner v. Parker, [2004] 1 BCLC 417 (Eng. Ct. App. 2004). In the US, SRL are frequently dismissed early in the case based on finding that the shareholder lacks standing to assert a claim for reflective loss. See Gaubert v. United States, 855 F.2d 1284 (5 ${ }^{\text {th }}$ Cir. 1989). In Canada, shareholder claims can be dismissed on a motion for summary judgment on the basis that the shareholder has no cause of action for reflective loss. See Meditrust HealthCare Inc. v. Shoppers Drug Mart, 61 O.R.(3d) 786 (Ont. Ct. App. 2002).

The ICJ has similarly dismissed a claim based on shareholder reflective loss at a preliminary stage. See Case Concerning Ahmadou Sadio Diallo (Republic of Guinea v. Democratic Republic of the Congo), Judgment on Preliminary Objections (2007) § 94 (rejecting at a preliminary stage for lack of standing a claim by Guinea to exercise diplomatic protection of a shareholder "by substitution" for host-state companies). 
primarily one of the nature of the loss and it can often be analysed and resolved without the need to resolve the complex factual and legal issues regarding liability. As discussed in Investment Treaties as Corporate Law, in most cases the direct or reflective nature of shareholder losses can be easily determined. Where the injuries are caused by a third party outsider to the company - the government - rather than by actions taken by a corporate insider such as a director, determination of the direct or reflective nature of shareholder losses may frequently be straightforward.

Many domestic systems and courts classify the issue as one going to the merits that is often suitable for preliminary determination. Some courts consider that the issue is jurisdictional in certain circumstances.

\section{b. $\quad$ Parties and tribunals have taken varying approaches to consideration of shareholder claims for reflective loss in ISDS}

There has been some conceptual uncertainty about the nature and treatment of objections to SRL in ISDS. Attempts to have SRL dismissed in preliminary decisions have been subject to varying procedural approaches. Some efforts to obtain early tribunal attention to shareholder claims have been refused. In Mondev v. United States, the US challenged the tribunal's competence over a claim by a shareholder for losses incurred by its wholly-owned US subsidiary. The US asked for preliminary resolution of its challenge. ${ }^{98}$ The tribunal rejected the request for early consideration of the shareholder claim issues and postponed them until the determination of the merits. ${ }^{99}$

The US framed its objection as one to the competence of the tribunal. ${ }^{100}$ The tribunal avoided the issue of the characterisation of the objection. ${ }^{101}$ It underlined the interests protected by the derivative action

The issue has been recognised as a purely legal issue in civil law countries. See Cass. Com. 15 Jan. 2002, 97-10886 (France) (rejecting shareholder claim for reflective loss for the purely legal reason [motif de pur droit] that the shareholder's loss was merely the corollary of that of the company and was accordingly not personal).

See Mondev International Ltd. v. United States, Award, ICSID (2002) § 17 (US requested consideration as a preliminary question of competence on grounds that, inter alia, Mondev did not own the rights at issue and that Mondev lacked standing under Article 1116 of NAFTA).

Id., $\S 26$.

See id. § 45 (Among the US objections to competence, "the United States also objected to the claim on the ground that any loss or damage had been suffered by LPA ('the enterprise'), and that the claim should accordingly have been brought on behalf of LPA under Article 1117 and not by Mondev on its own behalf. But since the notice of intention to submit the claim to arbitration did not refer to Article 1117 and did not contain the address of the enterprise, the claim must be considered as having been brought only under Article 1116.").

Id. $\S 46$ ("It is convenient to deal with these arguments together, irrespective of whether they may be considered as going to jurisdiction, admissibility or the merits."). 
mechanism ${ }^{102}$ and found that tribunals should ensure that recovery goes to the company where the company has incurred the loss. ${ }^{103}$

In some cases, jurisdictional and admissibility issues have been resolved in a preliminary decision, but the scope of the jurisdictional and admissibility inquiry does not reach the issue of SRL. This was notably the case in the $2003 C M S$ case. The tribunal did not address the nature of the losses, but denied the jurisdictional and admissibility objection. It framed the issue as whether shareholders can make claims for treaty breaches that are independent from those of the company concerned. This finding does not reach the issue of SRL since it is generally recognised that shareholders can bring separate claims for direct injury.

In other cases, however, tribunals appear to have resolved the question of the availability of recovery of reflective loss in jurisdictional decisions. ${ }^{104}$ In some situations, certain aspects of a challenge to SRL have been addressed in a preliminary phase, while others have been postponed to the merits. ${ }^{105}$ Thus, there remains some uncertainty about the procedural treatment of SRL and the scope of preliminary consideration of challenges to SRL in ISDS. ${ }^{106}$

The uncertainty about the procedural treatment of challenges to SRL has been masked by the considerable uniformity of outcomes with regard to most typical BITs in terms of allowing SRL. Tribunals have generally permitted SRL under typical BITs notwithstanding different approaches to resolving the issue. They have rejected objections to the availability of recovery of SRL whether framed as jurisdictional, admissibility, standing, improper plaintiff (claimant) or as related to the merits. As noted in Investment Treaties as Corporate Law, the reasons have also been largely the same (the inclusion of shares in the definition of investment and arbitral precedent).

The uncertainty about the procedural treatment of SRL may be of little moment for governments that seek to allow SRL generally in their treaties. For governments that wish to exclude or limit SRL, however, uncertainty about the procedural treatment of SRL may lead to unnecessary costs. Some governments may want to consider addressing whether respondent governments can require the tribunal to address in a

102 Id. $\S \S 84-85$ (recovery paid to the enterprise, not to the investor, "enable[s] third parties with, for example, security interests or other rights against the enterprise to seek to satisfy these out of the damages paid" and "could also make a difference in terms of the tax treatment of those damages"; multiple shareholder and company claims are avoided because "both the investor and the enterprise must waive the right to initiate or continue local proceedings").

103 Id. $\S 86$ ("Having regard to the distinctions drawn between claims brought under Articles 1116 and 1117 , a NAFTA tribunal should be careful not to allow any recovery, in a claim that should have been brought under Article 1117, to be paid directly to the investor.").

$104 \quad$ See, e.g., Continental Casualty v. Argentina, Decision on Jurisdiction, ICSID (2006) § 86 ("The Tribunal concludes therefore that it has jurisdiction to pass upon the present dispute, even assuming that the measures taken by Argentina and challenged by Continental as having breached its treaty rights were addressed and affected primarily or essentially the assets, investments, activities of the wholly owned subsidiary of Continental in Argentina.").

105 See Azurix Corp. v. Argentina, Decision on Jurisdiction (2003), §§ 67-74, 97-98, 101.

See also GAMI v. Mexico, Submission of the United States (non-disputing party) (30 June 2003) §§ 20, 1 (arguing that "a minority non-controlling shareholder may not bring a claim under the NAFTA for loss or damage incurred directly by an enterprise. A minority non-controlling shareholder has standing to bring a claim only for loss or damage to itself proximately caused by a breach"; taking no position on whether the issue of the availability of SRL goes "to the merits of the claim or the jurisdiction of the Tribunal"). 
preliminary decision the issue of the treaty limits on SRL and whether a claim is for (excluded) reflective loss and thus barred.

\section{c. $\quad$ Treaty practice}

Some governments have adopted treaty provisions that allow them to seek early dismissal of meritless claims. For example, following the decision in Mondev (and other cases involving preliminary objections), the US Model BIT was amended in 2004 to incorporate a provision allowing governments to compel early tribunal consideration of objections to the legal merits of claims:

Without prejudice to a tribunal's authority to address other objections as a preliminary question, a tribunal shall address and decide as a preliminary question any objection by the respondent that, as a matter of law, a claim submitted is not a claim for which an award in favour of the claimant may be made under Article $34 .{ }^{107}$

The Chile-Japan treaty similarly expressly provides for the mandatory preliminary resolution of any government objections relating to whether an award can be made in favour of the claimant. ${ }^{108}$

These provisions extend beyond jurisdictional (and admissibility) questions to the merits of the claim. The ability to obtain early dismissal is not constrained by whether the availability of SRL is considered to be jurisdictional. Nor is it constrained by a possibly narrow jurisdictional or admissibility inquiry. These provisions allow an early challenge to the legal merits of SRL.

Other treaties contain provisions on preliminary objections that apply to a narrower range of issues. For example, the Canadian 2004 Model BIT provides that "[w]here issues relating to jurisdiction or admissibility are raised as preliminary objections, a Tribunal shall, wherever possible, decide the matter before proceeding to the merits." ${ }^{109}$ Application of this provision to SRL would depend on the classification of the issue as one of jurisdiction or admissibility.

Beyond provisions that allow a government to require a preliminary decision on objections, tribunals generally have discretion to structure proceedings. They can bifurcate or trifurcate various questions. Tribunals frequently separate out jurisdictional issues; sometimes they include admissibility objections as well. As noted, however, the inquiry on these grounds may in some cases be too narrow to capture the issues raised by SRL. Tribunals are generally more reticent about early determinations relating to the merits. Those hesitations are one of the reasons for provisions that allow governments to compel early determinations of legal issues.

Some commentators have suggested, however, that some rules designed to streamline proceedings can be counterproductive because they introduce new issues for resolution and potentially additional steps to resolving a case. If the treaty generally permits SRL, providing a procedure for groundless preliminary legal challenges to the availability of SRL could lead to unnecessary costs and delay.

A provision allowing parties to compel an early arbitral decision on meritless claims was added to the ICSID Rules in 2006. ICSID Arbitration Rule 41 was amended to allow parties to object at the outset of

\footnotetext{
107 See US 2004 Model BIT, art. 28; US 2012 Model BIT, art. 28.

108 Chile-Japan, art. 97. See also Malaysia-New Zealand (art. 10.24).

109

Canada 2004 Model FIPA, art. 37; see also Peru-Singapore (art. 10.17(4) footnote 10-10).
} 
the case to claims which are "manifestly without legal merit" and to require the tribunal to issue a decision. ${ }^{110}$ This provision, however, applies only to ICSID cases; under many treaties, investors can avoid it by choosing a different arbitral forum.

An alternative approach could be to clarify or establish that treaty limitations or exclusions of SRL are jurisdictional in nature. This would be less certain with regard to the availability of early dismissal (a tribunal could refuse to bifurcate). It would also have broader consequences on the review of awards. (See below Section D.2 on "Treaty provisions governing review of decisions on shareholder claims for reflective loss in arbitral awards").

\section{Treaty provisions governing review of decisions on shareholder claims for reflective loss in} arbitral awards

Depending on their nature, decisions by ISDS arbitrators in arbitral awards are subject to varying standards of review. In particular, the characterisation of an issue as jurisdictional or not has a critical effect on the type of review applicable to the arbitrators' decision on the issue.

Awards can generally be annulled (or enforcement of the award can generally be denied) if the arbitrators exceed their jurisdiction. ${ }^{111}$ The reviewing body may conduct a significant inquiry into questions of jurisdiction. A treaty exclusion or limitation of SRL that is considered to be jurisdictional would allow arbitral decisions permitting SRL to be subject to annulment for excess of jurisdiction.

Errors of legal interpretation of a treaty generally do not affect the validity of the award. Unless the issue is considered to be jurisdictional, this would generally extend to a decision about whether a treaty allows for SRL. If the availability of SRL is only a question of law, an erroneous decision about whether SRL are permitted or barred generally would not affect the enforceability of the award.

There does not appear to be any express provisions in treaty practice on this issue. Treaties can provide or clarify that issues are jurisdictional in nature. However, as noted above, there has generally been a very limited degree of express attention to SRL in investment treaties. This extends to the question of characterising the issue for purposes of the scope of review.

\section{Issues for discussion}

- Does your government have experience with preliminary objections to SRL?

- Has your government adopted provisions allowing governments to compel tribunals to consider preliminary objections to meritless claims?

- What type of review, if any, is appropriate in your view for arbitral decisions determining the availability of SRL under a treaty? How do the practical consequences of decisions about the availability of SRL under a treaty compare with those of other types of decisions such as, for example, a decision that a promissory note is an investment?

\footnotetext{
$110 \quad$ ICSID Rule 41(5).

111 See, e.g., ICSID Convention, art. 52(1)(b) (annulment available if tribunal has manifestly exceeded its powers); New York Convention, art. V(1)(c). As set out in the ISDS Scoping Paper, review standards also include those under domestic law at the situs of the arbitration. See ISDS Scoping Paper, p. 33.
} 


\section{E. CONCLUSION}

As discussed in Investment Treaties as Corporate Law, the rules for SRL under typical BITs in ISDS contrast with those applied in advanced systems of domestic corporate law. SRL have been widely accepted under typical BITs in ISDS whereas they are generally barred under domestic law. Regulation of SRL under many treaties is very limited.

The case law over the last decade on the issue of the availability of SRL in ISDS under typical BITs has demonstrated remarkable consistency. Investor expectations that special ISDS rules on SRL will largely endure may lead them to structure investments in particular ways. In the interests of legal certainty, governments interested in considering and addressing the policy issues raised by SRL may want to do so promptly so that investor expectations are not unduly disrupted.

The regime for SRL in ISDS and its impact on expectations about business corporations have not yet been subject to academic policy analysis akin to that applied to domestic law corporate law rules in advanced jurisdictions. It is not clear that all governments have engaged in that analytical process in the case of their policy on SRL in ISDS. Even some major recent efforts to rethink ISDS have only skirted the issue of SRL. Corporate law and shareholder claims regimes involve some complex issues. Given the importance of specialised corporate law and investment law expertise for policy analysis in this area, there may be significant economies of scale and benefits in joint government attention to the issues raised by shareholder claims. 


\section{ANNEX I}

\section{A. EXCERPTS FROM SELECTED TREATIES}

\section{Energy Charter Treaty}

\section{Article 1 - Definitions}

As used in this Treaty: [...]

(6) "Investment" means every kind of asset, owned or controlled directly or indirectly by an Investor and includes: [...]

(b) a company or business enterprise, or shares, stock, or other forms of equity participation in a company or business enterprise, and bonds and other debt of a company or business enterprise;

(c) claims to money and claims to performance pursuant to contract having an economic value and associated with an Investment;

\section{Article 13 - Expropriation}

[...]

(3) For the avoidance of doubt, Expropriation shall include situations where a Contracting Party expropriates the assets of a company or enterprise in its Area in which an Investor of any other Contracting Party has an Investment, including through the ownership of shares.

\section{Article 17 - Non-Application of Part III in Certain Circumstances}

Each Contracting Party reserves the right to deny the advantages of this Part to:

(1) a legal entity if citizens or nationals of a third state own or control such entity and if that entity has no substantial business activities in the Area of the Contracting Party in which it is organized; or

(2) an Investment, if the denying Contracting Party establishes that such Investment is an Investment of an Investor of a third state with or as to which the denying Contracting Party:

(a) does not maintain a diplomatic relationship; or

(b) adopts or maintains measures that: 
(i) prohibit transactions with Investors of that state; or

(ii) would be violated or circumvented if the benefits of this Part were accorded to Investors of that state or to their Investments.

\section{Article 26 - Settlement of Disputes Between An Investor and A Contracting Party}

\section{$[\ldots]$}

(7) An Investor other than a natural person which has the nationality of a Contracting Party party to the dispute on the date of the consent in writing referred to in paragraph (4) and which, before a dispute between it and that Contracting Party arises, is controlled by Investors of another Contracting Party, shall for the purpose of article 25(2)(b) of the ICSID Convention be treated as "a national of another Contracting State" and shall for the purpose of article 1(6) of the Additional Facility Rules be treated as a "national of another State".

\section{Final Act of The European Energy Charter Conference - Understandings}

\section{$[\ldots]$}

\section{With respect to Article 1(6)}

For greater clarity as to whether an Investment made in the Area of one Contracting Party is controlled, directly or indirectly, by an Investor of any other Contracting Party, control of an Investment means control in fact, determined after an examination of the actual circumstances in each situation. In any such examination, all relevant factors should be considered, including the Investor's

(a) financial interest, including equity interest, in the Investment;

(b) ability to exercise substantial influence over the management and operation of the Investment; and

(c) ability to exercise substantial influence over the selection of members of the board of directors or any other managing body.

Where there is doubt as to whether an Investor controls, directly or indirectly, an Investment, an Investor claiming such control has the burden of proof that such control exists. 


\section{2. $\quad$ North American Free Trade Agreement (NAFTA)}

\section{Article 1113: Denial of Benefits}

1. A Party may deny the benefits of this Chapter to an investor of another Party that is an enterprise of such Party and to investments of such investor if investors of a non-Party own or control the enterprise and the denying Party:

(a) does not maintain diplomatic relations with the non-Party; or

(b) adopts or maintains measures with respect to the non-Party that prohibit transactions with the enterprise or that would be violated or circumvented if the benefits of this Chapter were accorded to the enterprise or to its investments.

2. Subject to prior notification and consultation in accordance with Articles 1803 (Notification and Provision of Information) and 2006 (Consultations), a Party may deny the benefits of this Chapter to an investor of another Party that is an enterprise of such Party and to investments of such investors if investors of a non-Party own or control the enterprise and the enterprise has no substantial business activities in the territory of the Party under whose law it is constituted or organized.

\section{Article 1116: Claim by an Investor of a Party on Its Own Behalf}

1. An investor of a Party may submit to arbitration under this Section a claim that another Party has breached an obligation under:

(a) Section A or Article 1503(2) (State Enterprises), or

(b) Article 1502(3)(a) (Monopolies and State Enterprises) where the monopoly has acted in a manner inconsistent with the Party's obligations under Section A, and that the investor has incurred loss or damage by reason of, or arising out of, that breach.

2. An investor may not make a claim if more than three years have elapsed from the date on which the investor first acquired, or should have first acquired, knowledge of the alleged breach and knowledge that the investor has incurred loss or damage.

\section{Article 1117: Claim by an Investor of a Party on Behalf of an Enterprise}

1. An investor of a Party, on behalf of an enterprise of another Party that is a juridical person that the investor owns or controls directly or indirectly, may submit to arbitration under this Section a claim that the other Party has breached an obligation under:

(a) Section A or Article 1503(2) (State Enterprises), or

(b) Article 1502(3)(a) (Monopolies and State Enterprises) where the monopoly has acted in a manner inconsistent with the Party's obligations under Section A, and that the enterprise has incurred loss or damage by reason of, or arising out of, that breach.

2. An investor may not make a claim on behalf of an enterprise described in paragraph 1 if more than three years have elapsed from the date on which the enterprise first acquired, or should have first acquired, knowledge of the alleged breach and knowledge that the enterprise has incurred loss or damage. 
3. Where an investor makes a claim under this Article and the investor or a non-controlling investor in the enterprise makes a claim under Article 1116 arising out of the same events that gave rise to the claim under this Article, and two or more of the claims are submitted to arbitration under Article 1120, the claims should be heard together by a Tribunal established under Article 1126, unless the Tribunal finds that the interests of a disputing party would be prejudiced thereby.

4. An investment may not make a claim under this Section.

\section{Article 1121: Conditions Precedent to Submission of a Claim to Arbitration}

1. A disputing investor may submit a claim under Article 1116 to arbitration only if:

(a) the investor consents to arbitration in accordance with the procedures set out in this Agreement; and

(b) the investor and, where the claim is for loss or damage to an interest in an enterprise of another Party that is a juridical person that the investor owns or controls directly or indirectly, the enterprise, waive their right to initiate or continue before any administrative tribunal or court under the law of any Party, or other dispute settlement procedures, any proceedings with respect to the measure of the disputing Party that is alleged to be a breach referred to in Article 1116, except for proceedings for injunctive, declaratory or other extraordinary relief, not involving the payment of damages, before an administrative tribunal or court under the law of the disputing Party.

2. A disputing investor may submit a claim under Article 1117 to arbitration only if both the investor and the enterprise:

(a) consent to arbitration in accordance with the procedures set out in this Agreement; and

(b) waive their right to initiate or continue before any administrative tribunal or court under the law of any Party, or other dispute settlement procedures, any proceedings with respect to the measure of the disputing Party that is alleged to be a breach referred to in Article 1117, except for proceedings for injunctive, declaratory or other extraordinary relief, not involving the payment of damages, before an administrative tribunal or court under the law of the disputing Party.

3. A consent and waiver required by this Article shall be in writing, shall be delivered to the disputing Party and shall be included in the submission of a claim to arbitration.

4. Only where a disputing Party has deprived a disputing investor of control of an enterprise:

(a) a waiver from the enterprise under paragraph 1(b) or 2(b) shall not be required; and

(b) Annex 1120.1(A)(b) shall not apply.

\section{Article 1126: Consolidation}

1. A Tribunal established under this Article shall be established under the UNCITRAL Arbitration Rules and shall conduct its proceedings in accordance with those Rules, except as modified by this Section. 
2. Where a Tribunal established under this Article is satisfied that claims have been submitted to arbitration under Article 1120 that have a question of law or fact in common, the Tribunal may, in the interests of fair and efficient resolution of the claims, and after hearing the disputing parties, by order:

(a) assume jurisdiction over, and hear and determine together, all or part of the claims; or

(b) assume jurisdiction over, and hear and determine one or more of the claims, the determination of which it believes would assist in the resolution of the others.

3. A disputing party that seeks an order under paragraph 2 shall request the Secretary-General to establish a Tribunal and shall specify in the request:

(a) the name of the disputing Party or disputing investors against which the order is sought;

(b) the nature of the order sought; and

(c) the grounds on which the order is sought.

4. The disputing party shall deliver to the disputing Party or disputing investors against which the order is sought a copy of the request.

5. Within 60 days of receipt of the request, the Secretary-General shall establish a Tribunal comprising three arbitrators. The Secretary-General shall appoint the presiding arbitrator from the roster referred to in Article 1124(4). In the event that no such presiding arbitrator is available to serve, the Secretary-General shall appoint, from the ICSID Panel of Arbitrators, a presiding arbitrator who is not a national of any of the Parties. The Secretary-General shall appoint the two other members from the roster referred to in Article 1124(4), and to the extent not available from that roster, from the ICSID Panel of Arbitrators, and to the extent not available from that Panel, in the discretion of the Secretary-General. One member shall be a national of the disputing Party and one member shall be a national of a Party of the disputing investors.

6. Where a Tribunal has been established under this Article, a disputing investor that has submitted a claim to arbitration under Article 1116 or 1117 and that has not been named in a request made under paragraph 3 may make a written request to the Tribunal that it be included in an order made under paragraph 2 , and shall specify in the request:

(a) the name and address of the disputing investor;

(b) the nature of the order sought; and

(c) the grounds on which the order is sought.

7. A disputing investor referred to in paragraph 6 shall deliver a copy of its request to the disputing parties named in a request made under paragraph 3.

8. A Tribunal established under Article 1120 shall not have jurisdiction to decide a claim, or a part of a claim, over which a Tribunal established under this Article has assumed jurisdiction.

9. On application of a disputing party, a Tribunal established under this Article, pending its decision under paragraph 2, may order that the proceedings of a Tribunal established under Article 1120 be stayed, unless the latter Tribunal has already adjourned its proceedings. 
10. A disputing Party shall deliver to the Secretariat, within 15 days of receipt by the disputing Party, a copy of:

(a) a request for arbitration made under paragraph (1) of Article 36 of the ICSID Convention;

(b) a notice of arbitration made under Article 2 of Schedule $\mathrm{C}$ of the ICSID Additional Facility Rules; or

(c) a notice of arbitration given under the UNCITRAL Arbitration Rules.

11. A disputing Party shall deliver to the Secretariat a copy of a request made under paragraph 3:

(a) within 15 days of receipt of the request, in the case of a request made by a disputing investor;

(b) within 15 days of making the request, in the case of a request made by the disputing Party.

12. A disputing Party shall deliver to the Secretariat a copy of a request made under paragraph 6 within 15 days of receipt of the request.

13. The Secretariat shall maintain a public register of the documents referred to in paragraphs 10,11 and 12 .

\section{Article 1135: Final Award}

1. Where a Tribunal makes a final award against a Party, the Tribunal may award, separately or in combination, only:

(a) monetary damages and any applicable interest;

(b) restitution of property, in which case the award shall provide that the disputing Party may pay monetary damages and any applicable interest in lieu of restitution.

A tribunal may also award costs in accordance with the applicable arbitration rules.

2. Subject to paragraph 1, where a claim is made under Article 1117(1):

(a) an award of restitution of property shall provide that restitution be made to the enterprise;

(b) an award of monetary damages and any applicable interest shall provide that the sum be paid to the enterprise; and

(c) the award shall provide that it is made without prejudice to any right that any person may have in the relief under applicable domestic law.

3. A Tribunal may not order a Party to pay punitive damages.

\section{Article 1139: Definitions}

For purposes of this Chapter: [...]

investment means: 
(a) an enterprise;

(b) an equity security of an enterprise;

(c) a debt security of an enterprise

(i) where the enterprise is an affiliate of the investor, or

(ii) where the original maturity of the debt security is at least three years,

but does not include a debt security, regardless of original maturity, of a state enterprise;

(d) a loan to an enterprise

(i) where the enterprise is an affiliate of the investor, or

(ii) where the original maturity of the loan is at least three years, but does not include a loan, regardless of original maturity, to a state enterprise;

(e) an interest in an enterprise that entitles the owner to share in income or profits of the enterprise;

(f) an interest in an enterprise that entitles the owner to share in the assets of that enterprise on dissolution, other than a debt security or a loan excluded from subparagraph (c) or (d);

$[\ldots]$

but investment does not mean,

(i) claims to money that arise solely from

(i) commercial contracts for the sale of goods or services by a national or enterprise in the territory of a Party to an enterprise in the territory of another Party, or

(ii) the extension of credit in connection with a commercial transaction, such as trade financing, other than a loan covered by subparagraph (d); or

(j) any other claims to money, that do not involve the kinds of interests set out in subparagraphs (a) through (h);

investment of an investor of a Party means an investment owned or controlled directly or indirectly by an investor of such Party;

\section{Annex 1120.1}

\section{Submission of a Claim to Arbitration - Mexico}

With respect to the submission of a claim to arbitration:

(a) an investor of another Party may not allege that Mexico has breached an obligation under:

(i) Section A or Article 1503(2) (State Enterprises), or 
(ii) Article 1502(3)(a) (Monopolies and State Enterprises) where the monopoly has acted in a manner inconsistent with the Party's obligations under Section A,

both in an arbitration under this Section and in proceedings before a Mexican court or administrative tribunal; and

(b) where an enterprise of Mexico that is a juridical person that an investor of another Party owns or controls directly or indirectly alleges in proceedings before a Mexican court or administrative tribunal that Mexico has breached an obligation under:

(i) Section A or Article 1503(2) (State Enterprises), or

(ii) Article 1502(3)(a) (Monopolies and State Enterprises) where the monopoly has acted in a manner inconsistent with the Party's obligations under Section A,

the investor may not allege the breach in an arbitration under this Section. 
3. Agreement among the Government of Japan, the Government of the Republic of Korea and the Government of the People's Republic of China for the Promotion, Facilitation and Protection of Investment

\section{Article 1- Definitions}

For the purposes of this Agreement:

(1) the term "investments" means every kind of asset that an investor owns or controls, directly or indirectly, which has the characteristics of an investment, such as the commitment of capital or other resources, the expectation of gain or profit, or the assumption of risk. Forms that investments may take include:

(a) an enterprise and a branch of an enterprise;

(b) shares, stocks or other forms of equity participation in an enterprise, including rights derived therefrom;

(c) bonds, debentures, loans and other forms of debt, including rights derived therefrom;

$[\ldots]$

(e) claims to money and claims to any performance under contract having a financial value associated with investment;

$[\ldots]$

Article 15 - Settlement of Investment Disputes between a Contracting Party and an Investor of Another Contracting Party

1. For the purposes of this Article, an investment dispute is a dispute between a Contracting Party and an investor of another Contracting Party that has incurred loss or damage by reason of, or arising out of, an alleged breach of any obligation of the former Contracting Party under this Agreement with respect to the investor or its investments in the territory of the former Contracting Party.

$[\ldots]$

5. Once the disputing investor has submitted an investment dispute to the competent court of the disputing Contracting Party or to one of the arbitrations set out in paragraph 3, the choice of the disputing investor shall be final and the disputing investor may not submit thereafter the same dispute to the other arbitrations set out in paragraph 3.

6. Notwithstanding paragraphs 3 and 4, no claim may be submitted to the arbitration set out in paragraph 3 unless the disputing investor gives the disputing Contracting Party written waiver of any right to initiate before any competent court of the disputing Contracting Party with respect to any measure of the disputing Contracting Party alleged to constitute a breach referred to in paragraph 1. 


\section{Article 22 - Denial of Benefits}

1. A Contracting Party may deny the benefits of this Agreement to an investor of another Contracting Party that is an enterprise of the latter Contracting Party and to its investments if the enterprise is owned or controlled by an investor of a non-Contracting Party and the denying Contracting Party:

(a) does not maintain normal economic relations with the non-Contracting Party; or

(b) adopts or maintains measures with respect to the non-Contracting Party that prohibit transactions with the enterprise or that would be violated or circumvented if the benefits of this Agreement were accorded to the enterprise or to its investments.

2. A Contracting Party may deny the benefits of this Agreement to an investor of another Contracting Party that is an enterprise of the latter Contracting Party and to its investments if the enterprise is owned or controlled by an investor of a non-Contracting Party or of the denying Contracting Party, and the enterprise has no substantial business activities in the territory of the latter Contracting Party.

Note: For the purposes of this Article, the term "non-Contracting Parties" shall not include any separate customs territory within the meaning of the General Agreement on Tariffs and Trade or of the WTO Agreement that is a member of the World Trade Organization as of the date of entry into force of this Agreement. 
4. Agreement between the Government of the United Mexican States and the Government of the People's Republic of China on the Promotion and Reciprocal Protection of Investments

\section{Article 1 - Definitions}

For the purposes of this Agreement, the term: [...]

"investment" means the assets owned or controlled by investors of a Contracting Party and acquired in accordance with the laws and regulations of the other Contracting Party, listed below:

(a) an enterprise;

(b) an equity security of an enterprise;

(c) a debt security of an enterprise

(i) where the enterprise is an affiliate of the investor, or

(ii) where the original maturity of the debt security is at least three years,

but does not include a debt security, regardless of original maturity, of a Contracting Party or of a State enterprise;

(d) a loan to an enterprise

(i) where the enterprise is an affiliate of the investor, or

(ii) where the original maturity of the loan is at least three years,

but does not include a loan, regardless of original maturity, to a Contracting Party or to a State enterprise;

(e) an interest in an enterprise that entitles the owner to share an income or profits of the enterprise;

(f) an interest in an enterprise that entitles the owner to share in the assets of that enterprise on dissolution, other than a debt security or a loan excluded from subparagraph (c) or (d) above;

\section{$[\ldots]$}

but investment does not mean,

(i) claims to money that arise solely from

(i) commercial contracts for the sale of goods or services by a national or enterprise in the territory of a Contracting Party to an enterprise in the territory of the other Contracting Party, or

(iii) the extension of credit in connection with a commercial transaction, such as trade financing, other than a loan covered by subparagraph (d) above, or 
(j) any other claims to money,

that do not involve the kinds of interests set out in subparagraphs (a) through (h) above;

$[\ldots]$

\section{Article 13 - Arbitration: Scope and Standing and Time Periods}

1. An investor of a Contracting Party may submit to arbitration a claim that the other Contracting Party has breached an obligation set forth in Chapter II, and that the investor has incurred loss or damage by reason of, or arising out of, that breach. ${ }^{112}$

$[\ldots]$

4. A disputing investor may submit a claim to arbitration only if: [...]

(b) the investor and, where the claim is for loss or damage to an interest of an enterprise of the other Contracting Party that is a legal person that the investor owns or controls, the enterprise waive their right to initiate or continue before any administrative tribunal or court under the laws of a Contracting Party, or other dispute settlement procedures, any proceedings with respect to the measure of the disputing Contracting Party that is alleged to be a breach of Chapter II, except for proceedings for injunctive, declaratory or other similar relief, not involving the payment of damages, before an administrative tribunal or court under the law of the disputing Contracting Party.

5. The consent and waiver referred to in this Article shall be in writing, delivered to the disputing Contracting Party and included in the submission of a claim to arbitration. ${ }^{113}$

\section{$[\ldots]$}

8. The Contracting Parties recognize that under this Article, minority non-controlling investors have standing to submit only a claim for direct loss or damage to their own legal interest as investors.

\section{Article 16 - Consolidation}

When a consolidation tribunal, with the Secretary General of ICSID acting as its appointing authority, is satisfied that the claims submitted before two or more tribunals under Article 15 have a question of fact or law in common, such consolidation tribunal may, in the interests of a fair and efficient resolution of the claims, consolidate the proceedings in accordance with the agreement of all disputing parties sought to be covered.

\section{Article 20 - Awards and Enforcement of Awards}

1. Unless the disputing parties agree otherwise, an award which provides that a Contracting Party has breached its obligations pursuant to this Agreement may only award, separately or in combination:

\footnotetext{
112 Annex B shall apply to this paragraph.

113 Annex $\mathrm{C}$ shall apply to this paragraph.
} 
(a) monetary damages and any applicable interest; or

(b) restitution in kind, provided that the Contracting Party may pay pecuniary compensation in lieu of restitution.

2. Where a claim is submitted to arbitration for loss or damages to an enterprise:

(a) an award of restitution in kind shall provide that restitution be made to the enterprise;

(b) an award of monetary damages and any applicable interest shall provide that the sum be paid to the enterprise; and

(c) the award shall provide that it is made without prejudice to any right that any person may have in the relief under applicable domestic law.

$[\ldots]$

\section{Article 31 - Denial of Benefits}

The Contracting Parties may decide jointly in consultation to deny the benefits of this Agreement to an enterprise of the other Contracting Party and to its investments, if a natural person or enterprise of a non-Contracting Party owns or controls such enterprise.

\section{Annex B - Annex to Article 13 paragraph 1}

An investor of a Contracting Party may not allege that the other Contracting Party has breached an obligation under Chapter II both in arbitration under Chapter III and in proceedings before a court or administrative tribunal of the latter Contracting Party. Where an enterprise of a Contracting Party that an investor of the other Contracting Party owns or controls alleges in proceedings before a court or administrative tribunal that the former Contracting Party has breached an obligation under this Agreement, the investor may not allege the breach in an arbitration under Chapter III.

\section{Annex C - Annex to Article 13 paragraph 5}

An investor shall go through the domestic administrative review procedures as specified by the laws and regulations of the disputing Contracting Party before the submission to international arbitration in accordance with Chapter III, Section One. If the domestic administrative review procedures are not complete within four (4) months after the date an application for the review is first filed, it shall be considered that the procedures are complete and the investor may proceed to an international arbitration. The investor may file an application for the review during the six (6) months consultation or negotiation period as provided in Article 12. 


\section{B. EXCERPTS FROM MODEL TREATIES}

\section{Netherlands 2004 Model Bilateral Investment Treaty}

\section{Article 1}

For the purposes of this Agreement:

(a) the term "investments" means every kind of asset and more particularly, though not exclusively:

(i) movable and immovable property as well as any other rights in rem in respect of every kind of asset;

(ii) rights derived from shares, bonds and other kinds of interests in companies and joint ventures;

(iii) claims to money, to other assets or to any performance having an economic value;

[...]

(b) the term "nationals" shall comprise with regard to either Contracting Party:

(i) natural persons having the nationality of that Contracting Party;

(ii) legal persons constituted under the law of that Contracting Party;

(iii) legal persons not constituted under the law of that Contracting Party but controlled, directly or indirectly, by natural persons as defined in (i) or by legal persons as defined in (ii).

\section{Article 9}

Each Contracting Party hereby consents to submit any legal dispute arising between that Contracting Party and a national of the other Contracting Party concerning an investment of that national in the territory of the former Contracting Party to the International Centre for Settlement of Investment Disputes for settlement by conciliation or arbitration under the Convention on the Settlement of Investment Disputes between States and Nationals of other States, opened for signature at Washington on 18 March 1965. A legal person which is a national of one Contracting Party and which before such a dispute arises is controlled by nationals of the other Contracting Party shall, in accordance with Article 25 (2) (b) of the Convention, for the purpose of the Convention be treated as a national of the other Contracting Party. 


\section{South African Development Community 2012 Model Bilateral Investment Treaty Template with Commentary}

\section{Article 2 - Definitions}

For the purposes of this Agreement: [...]

\section{Investment}

SPECIAL NOTE: The definition of investment is very critical and still very controversial. Three options are included here in full: an enterprise-based definition, a closed-list asset-based approach, and an open-list asset-based approach. These are presented in order from the least to the most expansive in terms of what they cover. The pros and cons of each will be fully explained in the final commentary of Article 2.

\section{ENTERPRISE-BASED DEFINITION}

Investment means an enterprise within the territory of one State Party established, acquired or expanded by an investor of the other State Party, including through the constitution, maintenance or acquisition of a juridical person or the acquisition of shares, debentures or other ownership instruments of such an enterprise, provided that the enterprise is established or acquired in accordance with the laws of the Host State[; and [registered][approved][recognized] in accordance with the legal requirements of the Host State]. An enterprise may possess assets such as:

1. Shares, stocks, debentures and other equity instruments of the enterprise or another enterprise

2. A debt security of another enterprise

3. Loans to an enterprise

4. Movable or immovable property and other property rights such as mortgages, liens or pledges

5. Claims to money or to any performance under contract having a financial value

\section{$[\ldots]$}

For greater certainty, Investment does not include:

1. Debt securities issued by a government or loans to a government

2. Portfolio investments

II. ASSET-BASED OPTION 1: CLOSED-LIST, EXHAUSTIVE TEST (BASED ON CANADIAN MODEL BIT)

Investment means the following assets admitted or established in accordance with the laws and regulations of the Party in whose territory the investment is made:

1. An enterprise 
2. An equity security of an enterprise

3. A debt security of an enterprise

(a) where the enterprise is an affiliate of the investor, or

(b) where the original maturity of the debt security is at least three years, but does not include a debt security, regardless of original maturity, of a State or State enterprise

4. A loan to an enterprise

(a) where the enterprise is an affiliate of the investor, or

(b) where the original maturity of the loan is at least three years, but does not include a loan, regardless of original maturity, to a State enterprise

5. An interest in an enterprise that entitles the owner to share in income or profits of the enterprise

6. An interest in an enterprise that entitles the owner to share in the assets of that enterprise on dissolution, other than a debt security or a loan excluded from subparagraphs (3) or (4) of this Article

\section{$[\ldots]$}

9. For greater certainty, an investment for the purposes of this Agreement does not include assets that are solely in the nature of portfolio investments; goodwill; market share, whether or not it is based on foreign origin trade, or rights to trade; claims to money deriving solely from commercial contracts for the sale of goods or services to or from the territory of a Party to the territory of the other Party, or a loan to a State Party or a State enterprise [...]

10. In order to qualify as an investment under this Agreement, an asset must have the characteristics of an investment, such as the [substantial] commitment of capital or other resources, the expectation of gain or profit, the assumption of risk, and significance for the Host State's development.

\section{OR}

\section{ASSET-BASED OPTION 2: NON-EXHAUSTIVE ASSET-BASED TEST (BASED ON U.S. MODEL TEXT)}

Investment means assets admitted or established in accordance with the laws and regulations of the Party in whose territory the investment is made, and includes:

1. Movable and immovable property and other related property rights such as mortgages, liens and pledges

2. Claims to money, goods, services or other performance having economic value

3. Stocks, shares and debentures of enterprises and interest in the property of such enterprises

$[\ldots]$ 
6. For greater certainty, an investment for the purposes of this Agreement does not include assets that are solely in the nature of portfolio investment; goodwill; market share, whether or not it is based on foreign origin trade, or rights to trade; claims to money deriving solely from commercial contracts for the sale of goods or services to or from the territory of a Party to the territory of the other Party, or a loan to a Party or to a State enterprise; a bank letter of credit; or the extension of credit in connection with a commercial transaction, such as trade financing.

7. In order to qualify as an investment under this Agreement, an asset must have the characteristics of an investment, such as the [substantial] commitment of capital or other resources, the expectation of gain or profit, the assumption of risk, and significance for the Host State's development.

\section{$[\ldots]$}

Portfolio investment means investment that constitutes less than 10 per cent of the shares of the company or otherwise does not give the portfolio investor the possibility to exercise effective management or influence on the management of the investment.

\section{Article 26 - Denial of Benefits}

26.1. A Party may at any time deny the benefits of this Agreement to an investor of another Party that is an enterprise of such Party and to investments of such investor if investors of a nonParty own or control the enterprise and the denying Party:

(a) does not maintain diplomatic relations with the non-Party, or

(b) adopts or maintains measures with respect to the non-Party that prohibit transactions with the enterprise or that would be violated or circumvented if the benefits of this Agreement were accorded to the enterprise or to its investments.

26.2. Subject to prior notification and consultation with the other State Party, a State Party may at any time deny the benefits of this Agreement to an investor of another Party that is an enterprise of such Party and to investments of such investors if investors of a non-Party own or control the enterprise and the enterprise has no substantial business activities in the territory of the Party under whose law it is constituted or organized.

\section{Article 29 - Investor-State Dispute Settlement}

\section{$[\ldots]$}

\subsection{Conditions for Submission of a Claim to Arbitration}

An Investor may submit a claim to arbitration pursuant to this Agreement, provided that:

(a) six months have elapsed since the Notice of Intent was filed with the State Party and no solution has been reached;

(b) the Investor or Investment, as appropriate,

(i) has first submitted a claim before the domestic courts of the Host State for the purpose of pursuing local remedies, after the exhaustion of any administrative remedies, relating to 
the measure underlying the claim under this Agreement, and a resolution has not been reached within a reasonable period of time from its submission to a local court of the Host State; or

(ii) the Investor demonstrates to a tribunal established under this Agreement that there are no reasonably available legal remedies capable of providing effective remedies of the dispute concerning the underlying measure, or the legal remedies provide no reasonable possibility of such remedies in a reasonable period of time.

(c) The Investor has provided a clear and unequivocal waiver of any right to pursue and/or to continue any claim relating to the measures underlying the claim made pursuant to this Agreement, on behalf of both the Investor and the Investment, before local courts in the Host State or in any other dispute settlement forum. 


\section{United States 2012 Model Bilateral Investment Treaty}

\section{Article 1: Definitions}

For purposes of this Treaty:

\section{$[\ldots]$}

"investment" means every asset that an investor owns or controls, directly or indirectly, that has the characteristics of an investment, including such characteristics as the commitment of capital or other resources, the expectation of gain or profit, or the assumption of risk. Forms that an investment may take include:

(a) an enterprise;

(b) shares, stock, and other forms of equity participation in an enterprise;

(c) bonds, debentures, other debt instruments, and loans; ${ }^{114}$

\section{$[\ldots]$}

\section{Article 17: Denial of Benefits}

1. A Party may deny the benefits of this Treaty to an investor of the other Party that is an enterprise of such other Party and to investments of that investor if persons of a non-Party own or control the enterprise and the denying Party:

(a) does not maintain diplomatic relations with the non-Party; or

(b) adopts or maintains measures with respect to the non-Party or a person of the non-Party that prohibit transactions with the enterprise or that would be violated or circumvented if the benefits of this Treaty were accorded to the enterprise or to its investments.

2. A Party may deny the benefits of this Treaty to an investor of the other Party that is an enterprise of such other Party and to investments of that investor if the enterprise has no substantial business activities in the territory of the other Party and persons of a non-Party, or of the denying Party, own or control the enterprise.

\section{Article 24: Submission of a Claim to Arbitration}

1. In the event that a disputing party considers that an investment dispute cannot be settled by consultation and negotiation:

(a) the claimant, on its own behalf, may submit to arbitration under this Section a claim

(i) that the respondent has breached

\footnotetext{
114 Some forms of debt, such as bonds, debentures, and long-term notes, are more likely to have the characteristics of an investment, while other forms of debt, such as claims to payment that are immediately due and result from the sale of goods or services, are less likely to have such characteristics.
} 

(A) an obligation under Articles 3 through 10,
(B) an investment authorization, or
(C) an investment agreement;

and

(ii) that the claimant has incurred loss or damage by reason of, or arising out of, that breach; and

(b) the claimant, on behalf of an enterprise of the respondent that is a juridical person that the claimant owns or controls directly or indirectly, may submit to arbitration under this Section a claim

(i) that the respondent has breached
(A) an obligation under Articles 3 through 10,
(B) an investment authorization, or
(C) an investment agreement;

and

(ii) that the enterprise has incurred loss or damage by reason of, or arising out of, that breach,

provided that a claimant may submit pursuant to subparagraph (a)(i)(C) or (b)(i)(C) a claim for breach of an investment agreement only if the subject matter of the claim and the claimed damages directly relate to the covered investment that was established or acquired, or sought to be established or acquired, in reliance on the relevant investment agreement.

\section{Article 26: Conditions and Limitations on Consent of Each Party}

1. No claim may be submitted to arbitration under this Section if more than three years have elapsed from the date on which the claimant first acquired, or should have first acquired, knowledge of the breach alleged under Article 24(1) and knowledge that the claimant (for claims brought under Article 24(1)(a)) or the enterprise (for claims brought under Article 24(1)(b)) has incurred loss or damage.

2. No claim may be submitted to arbitration under this Section unless:

(a) the claimant consents in writing to arbitration in accordance with the procedures set out in this Treaty; and

(b) the notice of arbitration is accompanied,

(i) for claims submitted to arbitration under Article 24(1)(a), by the claimant's written waiver, and

(ii) for claims submitted to arbitration under Article 24(1)(b), by the claimant's and the enterprise's written waivers 
of any right to initiate or continue before any administrative tribunal or court under the law of either Party, or other dispute settlement procedures, any proceeding with respect to any measure alleged to constitute a breach referred to in Article 24.

3. Notwithstanding paragraph 2(b), the claimant (for claims brought under Article 24(1)(a)) and the claimant or the enterprise (for claims brought under Article 24(1)(b)) may initiate or continue an action that seeks interim injunctive relief and does not involve the payment of monetary damages before a judicial or administrative tribunal of the respondent, provided that the action is brought for the sole purpose of preserving the claimant's or the enterprise's rights and interests during the pendency of the arbitration.

\section{Article 28: Conduct of the Arbitration}

$[\ldots]$

4. Without prejudice to a tribunal's authority to address other objections as a preliminary question, a tribunal shall address and decide as a preliminary question any objection by the respondent that, as a matter of law, a claim submitted is not a claim for which an award in favor of the claimant may be made under Article 34 .

(a) Such objection shall be submitted to the tribunal as soon as possible after the tribunal is constituted, and in no event later than the date the tribunal fixes for the respondent to submit its counter-memorial (or, in the case of an amendment to the notice of arbitration, the date the tribunal fixes for the respondent to submit its response to the amendment).

(b) On receipt of an objection under this paragraph, the tribunal shall suspend any proceedings on the merits, establish a schedule for considering the objection consistent with any schedule it has established for considering any other preliminary question, and issue a decision or award on the objection, stating the grounds therefor.

(c) In deciding an objection under this paragraph, the tribunal shall assume to be true claimant's factual allegations in support of any claim in the notice of arbitration (or any amendment thereof) and, in disputes brought under the UNCITRAL Arbitration Rules, the statement of claim referred to in Article 20 of the UNCITRAL Arbitration Rules. The tribunal may also consider any relevant facts not in dispute.

(d) The respondent does not waive any objection as to competence or any argument on the merits merely because the respondent did or did not raise an objection under this paragraph or make use of the expedited procedure set out in paragraph 5.

5. In the event that the respondent so requests within 45 days after the tribunal is constituted, the tribunal shall decide on an expedited basis an objection under paragraph 4 and any objection that the dispute is not within the tribunal's competence. The tribunal shall suspend any proceedings on the merits and issue a decision or award on the objection(s), stating the grounds therefor, no later than 150 days after the date of the request. However, if a disputing party requests a hearing, the tribunal may take an additional 30 days to issue the decision or award. Regardless of whether a hearing is requested, a tribunal may, on a showing of extraordinary cause, delay issuing its decision or award by an additional brief period, which may not exceed 30 days.

6. When it decides a respondent's objection under paragraph 4 or 5 , the tribunal may, if warranted, award to the prevailing disputing party reasonable costs and attorney's fees incurred in submitting or opposing the objection. In determining whether such an award is warranted, the 
tribunal shall consider whether either the claimant's claim or the respondent's objection was frivolous, and shall provide the disputing parties a reasonable opportunity to comment.

$[\ldots]$

\section{Article 33: Consolidation}

1. Where two or more claims have been submitted separately to arbitration under Article 24(1) and the claims have a question of law or fact in common and arise out of the same events or circumstances, any disputing party may seek a consolidation order in accordance with the agreement of all the disputing parties sought to be covered by the order or the terms of paragraphs 2 through 10 .

2. A disputing party that seeks a consolidation order under this Article shall deliver, in writing, a request to the Secretary-General and to all the disputing parties sought to be covered by the order and shall specify in the request:

(a) the names and addresses of all the disputing parties sought to be covered by the order;

(b) the nature of the order sought; and

(c) the grounds on which the order is sought.

3. Unless the Secretary-General finds within 30 days after receiving a request under paragraph 2 that the request is manifestly unfounded, a tribunal shall be established under this Article.

4. Unless all the disputing parties sought to be covered by the order otherwise agree, a tribunal established under this Article shall comprise three arbitrators:

(a) one arbitrator appointed by agreement of the claimants;

(b) one arbitrator appointed by the respondent; and

(c) the presiding arbitrator appointed by the Secretary-General [of ICSID], provided, however, that the presiding arbitrator shall not be a national of either Party.

\section{$[\ldots]$}

9. A tribunal established under Article 27 [Selection of Arbitrators] shall not have jurisdiction to decide a claim, or a part of a claim, over which a tribunal established or instructed under this Article has assumed jurisdiction.

\section{Article 34: Awards}

$[\ldots]$

2. Subject to paragraph 1, where a claim is submitted to arbitration under Article 24(1)(b):

(a) an award of restitution of property shall provide that restitution be made to the enterprise;

(b) an award of monetary damages and any applicable interest shall provide that the sum be paid to the enterprise; and

(c) the award shall provide that it is made without prejudice to any right that any person may have in the relief under applicable domestic law. 


\section{INFORMATION ON CITED TREATIES}

This part of the annex provides the full name in English (unless unavailable), the year of signature and, where available, a link to the text of the treaties cited in the paper. The list includes treaties that have yet to enter into force or are not currently in force.

Argentina-Germany: Vertrag zwischen der Bundesrepublik Deutschland und der Argentinischen Republik über die Förderung und den gegenseitigen Schutz von Kapitalanlagen; Tratado entre la República Federal de Alemania y la República Argentina sobre Promoción y Protección Recíproca de Inversiones (1991)

Argentina-United States: Treaty between the United States of America and the Argentine Republic concerning the Reciprocal Encouragement and Protection of Investment (1991)

ACIA: ASEAN Comprehensive Investment Agreement (2009)

ASEAN-China: Agreement on Investment of the Framework Agreement on Comprehensive Economic Co-operation between the Association of Southeast Asian Nations and the People's Republic of China (2009)

CAFTA-DR: Dominican Republic-Central America-United States Free Trade Agreement (2004)

Canada-Czech Republic: Agreement Between the Government of Canada and the Government of the Czech and Slovak Federal Republic for the Promotion and Protection of Investments (2009)

Canada-Hungary: Agreement between the Government of Canada and the Government of the Republic of Hungary for the Promotion and Reciprocal Protection of Investments (1991)

Canada-Peru: Agreement Between Canada and the Republic of Peru for the Promotion and Protection of Investments (2006)

Canada 2004 Model FIPA: Agreement between Canada and [...] for the Promotion and Protection of Investments

Chile-Japan: Agreement between Japan and the Republic of Chile for a Strategic Economic Partnership (2007)

Chile-Mexico: Tratado de Libre Comercio entre el Gobierno de la República de Chile y el Gobierno de los Estados Unidos Mexicanos (1998)

China-Germany: Agreement between the People's Republic of China and the Federal Republic of Germany on the Encouragement and Reciprocal Protection of Investments (2003)

China-Japan-Korea: Agreement among the Government of Japan, the Government of the Republic of Korea and the Government of the People's Republic of China for the Promotion, Facilitation and Protection of Investment (2012)

China-Mexico: Agreement between the Government of the United Mexican States and the Government of the People's Republic of China on the Promotion and Reciprocal Protection of Investments (2008) 


\section{Energy Charter Treaty (ECT) (1994)}

France 2006 Model BIT: Accord entre le Gouvernement de la République Française et le Gouvernement de [ ] sur l'Encouragement et la Protection Réciproque des investissements (English version)

Germany 2008 Model BIT: Treaty between the Federal Republic of Germany and $[\ldots]$ concerning the Encouragement and Reciprocal Protection of Investments

Japan-Turkey: Agreement between Japan and the Republic of Turkey Concerning the Reciprocal Promotion and Protection of Investment (1992)

Malaysia-New Zealand: New Zealand - Malaysia Free Trade Agreement (2009)

Mercosur Protocol of Colonia: Protocolo de Colonia para la Promoción y Protección Recíproca de Inversiones en el MERCOSUR (1994)

North American Free Trade Agreement (NAFTA), chapter 11 (1992)

Netherlands 2004 Model BIT: Agreement on Encouragement and Reciprocal Protection of Investments between $[\ldots]$ and the Kingdom of the Netherlands

Peru-Singapore: Peru-Singapore Free Trade Agreement (2008)

Russian Federation-UK: Agreement between the Government of the United Kingdom of Great Britain and Northern Ireland and the Government of the Union of Soviet Socialist Republics for the Promotion and Reciprocal Protection of Investment (1989)

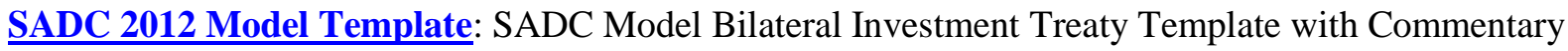

UK 2005 Model BIT: Draft Agreement between the Government of the United Kingdom of Great Britain and Northern Ireland and the Government of [...] the Promotion and Protection of Investments ${ }^{115}$

United States-Czech Republic, US-Slovak Republic: Treaty with the Czech and Slovak Federal Republic Concerning the Reciprocal Encouragement and Protection of Investment (1991)

United States 2004 Model BIT: Treaty between the Government of the United States of America and the Government of [country] Concerning the Encouragement and Reciprocal Protection of Investment

United States 2012 Model BIT: Treaty between the Government of the United States of America and the Government of [country] Concerning the Encouragement and Reciprocal Protection of Investment

$115 \quad$ Reproduced in Campbell McLachlan et al, International Investment Arbitration: Substantive Principles (2007), Appendix 4. 


\title{
OECD Working Papers on International Investment
}

\author{
http://www.oecd.org/daf/inv/investment-policy/working-papers.htm
}

2014

2014/2 Investment Treaties and Shareholder Claims for Reflective Loss: Insights from Advanced Systems of Corporate Law

2014/1 Investment Treaty Law, Sustainable Development and Responsible Business Conduct: A Fact Finding Survey

2013

$2013 / 4$

Temporal validity of international investment agreements: a large sample survey of treaty provisions

$2013 / 3$

Investment treaties as corporate law: Shareholder claims and issues of consistency

$2013 / 2$

Lessons from Investment Policy Reform in Korea

$2013 / 1$

China Investment Policy: an Update

2012

Investor-state dispute settlement: A scoping paper for the investment policy community

Dispute settlement provisions in international investment agreements: A large sample survey

$2012 / 1$

Corporate greenhouse gas emission reporting: A stocktaking of government schemes

2011

$2011 / 2$

Defining and measuring green FDI: An exploratory review of existing work and evidence

$2011 / 1$

Environmental concerns in international investment agreements: a survey

2010

$2010 / 3$

OECD's FDI Restrictiveness Index: 2010 Update

$2010 / 2$

Foreign state immunity and foreign government controlled investors

$2010 / 1$

Intellectual property rights in international investment agreements

2006

$2006 / 4$

OECD's FDI regulatory restrictiveness index: Revision and extension to more economies

$2006 / 3$

Interpretation of the Umbrella Clause in Investment Agreements

$2006 / 2$

Investor-State Dispute Settlement in Infrastructure Projects

$2006 / 1$

Improving the System of Investor-State Dispute Settlement: An Overview

2005

Corporate Responsibility Practices of Emerging Market Companies - A Fact-Finding Study 
Mobilising Investment for Development: Role of ODA - The 1993-2003 Experience in Vietnam ODA and Investment for Development: What Guidance can be drawn from Investment Climate Scoreboards?

Indirect Expropriation and the Right to Regulate in International Investment Law

Fair and Equitable Treatment Standard in International Investment Law

Most-Favoured-Nation Treatment in International Investment Law

Relationships between International Investment Agreements

\section{Business Approaches to Combating Corrupt Practices}

Incentives-based Competition for Foreign Direct Investment: The Case of Brazil

Managing Working Conditions in the Supply Chain: A Fact-Finding Study of Corporate Practices Multinational Enterprises in Situations of Violent Conflict and Widespread Human Rights Abuses

Codes of Corporate Conduct: Expanded review of their contents The OECD Guidelines for Multinational Enterprises and other corporate responsibility instruments Public policy and voluntary initiatives: What roles have governments played? Making codes of corporate conduct work: Management control systems and corporate responsibility Corporate Responsibility: Results of a fact-finding mission on private initiatives Private Initiatives for Corporate Responsibility: An Analysis

Recent trends, policies and challenges in South East European countries

Main determinants and impacts of FDI on China's economy

Lithuania: Foreign Direct Investment Impact and Policy Analysis

Investment Patterns in a Longer-Term Perspective

Bribery and the business sector: Managing the relationship

Rules for the Global Economy: Synergies between Voluntary and Binding Approaches

Deciphering Codes of Corporate Conduct: A Review of their Contents

Southeast Asia: the Role of FDI Policies in Development

Survey of OECD work on international investment 